\title{
Sindicalismo, propaganda y participación electoral: el Partido Obrero Socialista en Viña del Mar. 1913-1922
}

\author{
Syndicalism, propaganda and electoral participation: the Socialist Workers \\ Party in Viña del Mar. 1913-1922
}

\author{
Diego Riffo Soto*
}

\begin{abstract}
Resumen: El siguiente artículo tiene por objetivo analizar el proceso que llevó el Partido Obrero Socialista a hegemonizar el movimiento obrero en la ciudad de Viña del Mar, convirtiéndose en uno de los actores políticos más relevante de aquella localidad. Para esto, nos centraremos en tres elementos relevantes del actuar político de los socialistas: la acción propagandística, las huelgas y las elecciones municipales. Lo anterior a través del análisis de fuentes periodísticas, en especial una poco tratada por la historiografía, como es el periódico La Comuna, proponemos matizar tanto las miradas que han centrado en el norte salitrero el espacio excepcional de la organización obrera, así como la influencia del anarquismo en la zona central del país.
\end{abstract}

Palabras clave: Partido Obrero Socialista, Viña del Mar, huelga, elección municipal.

\begin{abstract}
The following article aims to analyze the process that led the Socialist Workers Party to hegemonize the labor movement in the city of Viña del Mar, becoming one of the most relevant political actors of that town. For this, we will focus on three relevant elements of the socialist political action: the propaganda action, the syndical action of the POS and the municipal elections. The foregoing through the analysis of journalistic sources, especially a little treated by historiography, such as the newspaper La Comuna, we propose to qualify both the views that have focused on the nitrate north the exceptional space of the workers' organization, as well as the influence of anarchism in the central zone of the country.
\end{abstract}

Key words: Socialist Worker Party, Viña del Mar, syndicalism, municipal election.

Recibido: 27 marzo 2017

Aceptado: 30 junio 2017

\footnotetext{
* Chileno, Profesor de Historia y Ciencias Sociales. Licenciado en Educación e Historia por la Universidad de Valparaíso. Correo: diego.riffo.s@gmail.com
} 


\section{Introducción}

En 1983, el historiador estadounidense Peter DeShazo publicaba Trabajadores urbanos y sindicatos en Chile: 1902-1927 , cuyo objetivo fue el estudio del movimiento obrero durante las primeras décadas del siglo XX en las ciudades de Santiago y Valparaíso, dos de los núcleos urbanos más relevantes no solo en términos económicos y comérciales, sino que también industriales, lo que se tradujo en una concentración de una importante fuerza laboral, permitiendo la organización de los trabajadores que buscaban mejoras en las condiciones laborales y de vida en general. La hipótesis que atraviesa dicha investigación es que las fuerzas más dinámicas del movimiento obrero en zonas urbanas de la zona central del país, fue la del anarcosindicalismo. Sin embargo, es posible preguntarse ¿Qué ocurrió en otras ciudades del país más allá de Valparaíso y Santiago? ¿Qué sucedió con otros actores políticos que disputaban con el anarquismo y anarcosindicalismo la hegemonía del movimiento obrero?

El Partido Obrero Socialista (POS) fue uno de esos actores que disputó a los ácratas la hegemonía del movimiento obrero a nivel nacional. Este partido logró articular secciones no solo en la zona salitrera, en donde fue fundado, sino que a lo largo del país. Una de las más relevante fue la de Viña del Mar, ubicada a pocos kilómetros de Valparaíso y en donde lograron un claro liderazgo en el movimiento obrero local, lo que nos permite cuestionar lo señalado en el libro de DeShazo anteriormente mencionado. ¿Cómo logró el POS esto? Proponemos, a modo de hipótesis, que el POS alcanzó posicionarse en el movimiento obrero viñamarino gracias a un abanico de estrategias, a las que hemos denominados como los "tres pilares": a) la creación de una serie de organismos obreros de los cuales, siendo los más relevantes los consejos federales de la FOCh y que permitió movilizar a un considerable número de trabajadores en distintas huelgas como táctica de presión; b) el desarrollo de un periódico propio y c) la participación en la institucionalidad política, lo que llevó a la sección viñamarina del partido a disputar una serie de elecciones, logrando el triunfo de su máximo dirigente, Ramón Sepúlveda Leal, quién se incorporó al municipio como regidor.

La opción temporal corresponde a hechos relevantes para la presente investigación: 1913, fecha en la que podemos rastrear los primeros indicios de los socialistas en la ciudad, mientras que en 1922, ocurren dos sucesos que marcarán a la sección: el POS pasó a convertirse en Partido Comunista (PCCh), instalándose el Consejo Ejecutivo Nacional (CEN) en Viña del Mar, demostrando así la importancia que adquirió la sección de esta ciudad y en segundo lugar, la expulsión de Ramón Sepúlveda Leal de su cargo de regidor municipal en el mes de agosto producto de una acción judicial interpuesta por un antiguo contendiente electoral. Hemos dividido en dos etapas el periodo estudiado: la primera, la hemos denominado de formación e inserción, el cual va desde 1913-1917 y se caracterizó por la construcción partidaria, mientras intentaban hacerse un camino en distintos frentes

\footnotetext{
${ }^{1}$ Para el presente artículo se ha trabajado con la versión en español del libro, Peter DeShazo, Trabajadores urbanos y sindicatos en Chile: 1902-1927, Santiago de Chile, Centro de Investigación Diego Barros Arana, 2007.
} 
sociales y sindicales de la ciudad. La segunda, se caracterizó por ser un momento de avance y consolidación de los militantes del POS en Viña del Mar, abarcando desde 1918 hasta principios de 1922, al que hemos denominado de consolidación. Por tanto, el artículo estará dividido en dos, en donde se analizarán con detención cada una de las etapas anteriormente mencionadas.

A través de una metodología de revisión de fuentes primarias, principalmente periódicos y actas municipales, intentamos reconstruir parte de la historia del movimiento obrero urbano viñamarino y del POS, pero también de la ciudad, toda vez que este trabajo se integra bajo las líneas historiográficas de historia local e historia política. Lo anterior, complementado con una revisión a la bibliografía disponible en torno al $\mathrm{POS}^{2}$, del movimiento obrero y de Viña del Mar.

\section{Formación e inserción de los socialistas en Viña del Mar (1913-1917).}

La ciudad de Viña del Mar tuvo desde sus orígenes un carácter marcadamente industrial, existiendo cerca de 31 fábricas para el periodo que va desde 1870 y 1917 , convirtiéndose en la más insigne, la Compañía Refinería de Azúcar de Viña del Mar (CRAV). Este carácter industrial fue facilitado por su cercanía a Valparaíso y la articulación que permitió la red ferroviaria entre el puerto y el interior de la provincia, pasando por Viña del Mar. Así fue posible un temprano crecimiento del contingente obrero, que experimentó un explosivo desarrollo entre finales del siglo XIX y las dos primeras décadas del siglo XX, cuando se triplicó la población de Viña del Mar³. De allí que, ni la zona central del país en general, ni Viña del Mar en particular, pasaron desapercibido por los socialistas, quienes realizaron grandes esfuerzos, desde su fundación, en el crecimiento del POS en esta zona. También ello puede explicar, entre múltiples factores, porque su primer secretario general no fuera su más destacado militante, Luis Emilio Recabarren, sino que Ramón Sepúlveda Leal, principal dirigente socialista de Viña del Mar. No obstante, estos rasgos de la por entonces industrial ciudad, han sido dejados de lado como espacio de

\footnotetext{
${ }^{2}$ Es importante señalar que las investigaciones del POS se han concentrado principalmente en la zona del norte salitrero del país, los cuales podemos destacar Julio Pinto y Verónica Valdivia, ¿Revolución proletaria o querida chusma?: Socialismo y Alessandrismo en la pugna por la politización pampina (1911-1932), Santiago de Chile, LOM Ediciones, 2001; Julio Pinto, Desgarros y utopías en la pampa salitrera. La consolidación de la identidad obrera en tiempos de la cuestión social (1890-1923), Santiago de Chile, LOM Ediciones, 2007; Julio Pinto, Socialismo y salitre: Recabarren, Tarapacá y la formación del Partido Obrero Socialista, Historia, vol. 32, 1999. Sin embargo, nuevos estudios sobre el partido han ampliado la panorámica, incluyendo zonas antes poco trabajada. Destacan los trabajos de Sergio Grez, La Historia del Comunismo en Chile. La era de Recabarren (1912-1924), Santiago de Chile, LOM Ediciones, 2011; Daniel Riquelme, Identidad y proyecto político en la construcción del Partido Obrero Socialista. Santiago y Valparaíso, 19121916; Diego Riffo, “Por las Fábricas de Viña del Mar!: La presencia del Partido Obrero Socialista en Viña del Mar. 1919-1921. Un análisis a través del periódico La Comuna”. Tesis para optar a los grados académicos de Licenciado en Historia, Licenciado en Educación y Título Profesional de Profesor de Enseñanza Media en Historia y Ciencias Sociales, Valparaíso, 2016; Jorge Navarro, Revolucionarios y parlamentario. La cultura política del Partido Obrero Socialista, 1912-1922; Santiago de Chile, LOM Ediciones, 2017.

${ }^{3}$ María Ximena Urbina, Chalets y Chimeneas: los primeros establecimientos industriales viñamarinos, 1870 1920. Revista Archivum, año IV, No, Viña del Mar, 2003, p. 177.
} 
análisis del movimiento sindical, siendo apenas nombrados en los estudios sobre la acción obrera porteña o, en el mejor de los casos, siendo considerada como una mera "extensión" del desarrollo socialista en Valparaíso.

Como han dado cuenta otras investigaciones, la fundación de las secciones del POS en el centro del país se dieron hacia finales del $1912^{4}$ y principio de $1913^{5}$. Si bien al parecer en muchas zonas se había incubado un descontento en el seno del Partido Democrático (PD), a partir de la cual se dividieron distintos grupos de militantes que habían participado en la corriente "socialista" al interior de dicha organización o habían sido impactados por la noticia de la construcción de una nueva organización de obreros y socialistas en Tarapacá, esto no significó que este grupo se aunara, y por varios años mantuvo una debilidad orgánica y cierta fragmentariedad para actuar en el naciente partido. Esta realidad, que Sergio Grez data al menos hasta el Congreso de 1915 y que denomina como "dispersión inicial", evidenciaba que lo existente, al menos por esos años, era una serie de agrupaciones socialistas, que carecían de una Dirección Nacional y de comunicaciones fluidas entre las distintas secciones ${ }^{7}$. El alto grado de autonomía con la que actuaban estos núcleos, como plantea Grez, no dejan de llamar la atención, pues evidencian que la construcción del POS respondió a una necesidad de diversos actores sociales de la época y no necesariamente a una estrategia deliberada. Aunque el despliegue de un trabajo más uniforme y articulado se transformó en una preocupación central con el correr de los años, la carencia de dicha estrategia no inhibió la práctica de los militantes socialistas, sino que a dicha carencia respondieron con el hacer. Por tanto, se hace necesario analizar por qué y cómo se desarrolló un núcleo de la nueva colectividad en Viña del Mar, para explicar su rápido avance en la ciudad.

Estos años que han sido caracterizados como la formación del proyecto, la identidad y la cultura política propia del $\mathrm{POS}^{8}$, para diferenciarse de los demócratas y anarquistas estando fuertemente influenciada por la realidad de las zonas en que se desplegó, en este caso, del centro articulado en torno a Valparaíso. Es en este puerto, donde la presencia de los socialistas se dio relativamente temprano en comparación a otras partes del país ${ }^{9}$. En base a lo anterior, se fueron desplegando tres ejes en la práctica de la agrupación socialista porteña por esos años: la propaganda, la acción sindical, y la participación electoral. A estos ejes los hemos denominados los "tres pilares" de la acción socialista y serán posteriormente replicados en Viña del Mar con bastante éxito.

La difusión de las ideas del partido a través de órganos periodísticos fue fundamental para el POS y estaban ligados a una, como lo define Guillermo Sunkel, matriz racional-iluminista relacionada a las corrientes nacidas del iluminismo europeo, como el

\footnotetext{
${ }^{4}$ Grez (b), op. cit., p. 37.

${ }^{5}$ Navarro, op. cit., p. 44.

${ }^{6}$ Sergio Grez, El Partido Democrático de Chile. Auge y ocaso de una organización política popular (18871927), LOM Ediciones, Santiago de Chile, 2016, p. 218.

${ }^{7}$ Grez (b), op.cit., p.37.

${ }^{8}$ Riquelme, op.cit., Navarro, op.cit.

${ }^{9}$ Grez (b); op.cit. p. 25 . El autor señala que a finales de 1912 se fundó en la ciudad de Viña del Mar, un "Partido Obrero" cuyo presidente fue Israel Oyaneder, no quedando claro si fue un intento por fundar una sección del POS en la ciudad o no.
} 
liberalismo, radicalismo, anarquismo y marxismo y que compartían ciertas ideas en comunes, como una postura antirreligiosa, anticlerical, la convicción en la razón como medio de progreso y la concepción de que el pueblo debe ser civilizado toda vez que se encuentra en un estado de atraso ${ }^{10}$. Los periódicos de los socialistas de las primeras décadas del siglo XX se inscriben en esta línea y ejemplo de ello son La Defensa Obrera, El Socialista, La Vanguardia, publicados en Valparaíso y La Comuna, que fue el periódico de la sección viñamarina tanto del POS como de la FOCh, el cual se analizará con mayor detalle posteriormente. En estos periódicos (y otros editados por el partido a lo largo del país) podemos encontrar dos características comunes de la prensa popular del periodo: el público a que fueron dirigidos fue principalmente el proletario, pero también al minero, al campesino, al empleado público, al pequeño comerciante, es decir, a las y los trabajadores en general y en segundo lugar, tanto en su circulación como en el lenguaje, la prensa popular del periodo era localista, lo que permitía generar una identidad tanto político-social como localista ${ }^{11}$.

El segundo "pilar" estaba dado por la concepción socialista que el POS propugnaba. Reafirmando la división de clase, entre trabajadores y capitalistas, el partido buscó como objetivo eliminar esta división para "convertir a todos los hombres en una sola clase, de trabajadores inteligentes, iguales y libres, y para implementar un régimen en que la producción sea un factor común y también el goce de los productos" "12. Esto lo llevarían a cabo organizando "a todos los trabajadores de todos los gremios y oficios en federaciones de resistencia con cajas de fondas dedicadas esencialmente al sostén de las luchas entre el capital y el trabajo" "13. Fue así como el POS, en todos los lugares en que levantó secciones, buscó vincularse con el movimiento obrero, ya sea creando organizaciones, reactivando algunas ya creadas pero que habían quedado olvidadas o incorporándose a alguna para luego ir disputando los espacios hasta tener mayoría. La FOCh será el caso emblemático de este último ejemplo.

Finalmente, la participación en la institucionalidad política, reflejada en las elecciones, será el tercer "pilar" del POS, demostrando la influencia del PD en los militantes socialistas, principalmente de Luis Emilio Recabarren. ${ }^{14}$ Sin embargo lo anterior, la declaración de principios del POS hacía una fuerte crítica a todos los partidos políticos existente, señalando que los socialistas utilizarían las elecciones para:

quitar a la burguesía el poder político, a fin de que cese ser instrumento de dominación; realizaremos obra de saneamiento político llevando a las diputaciones representantes de nuestra clase que impongan nuestro programa; invadiremos las municipalidades para hacer obra de higienización en las poblaciones, abolir los impuestos a los artículos

\footnotetext{
${ }^{10}$ Sunkel, Guillermo, Razón y pasión en la prensa popular. Un estudio sobre cultura popular, cultura de masas y cultura política, Publicaciones El Buen Aire S.A, Santiago, 2016, p.52

${ }^{11}$ Sunkel, op.cit., p.24.

12 Programa del Partido Obrero Socialista, Fernando Ortiz, El Movimiento Obrero en Chile (1891-1919), Santiago de Chile, LOM Ediciones, p.245.

13 Ibid, p. 246.

14 Jaime Massardo, La formación del imaginario político de Luis Emilio Recabarren. Contribución al estudio crítico de la cultura política de las clases subalternas de la sociedad chilena, Santiago de Chile, LOM Ediciones, p.163.
} 
de primera necesidad para la vida y haciendo que los servicios de utilidad general estén en manos de las mismas municipalidades y no sirvan como objeto de lucro de particulares. ${ }^{15}$

A través de estos "pilares", los socialistas comenzaron a tener una inserción cada vez más importante en la zona central del país. Uno de los primeros conflictos en donde se ve reflejado su actuar es en el puerto de Valparaíso, en la denominada "Huelga del Mono" del año $1913^{16}$. Dicha movilización, permitió un inédito trabajo en conjunto entre sectores anarquistas, representados en la Federación Obrera Regional de Chile (FORCh) y socialistas, en donde destacarían algunos nombres de dirigentes del POS, entre ellos, el militante de la futura sección viñamarina, Ramón Sepúlveda Leal ${ }^{17}$.

La "Huelga del Mono" afectó a las industrias ubicadas en Viña del Mar una vez que la movilización se extendió a la vecina ciudad. Sin embargo, la paralización tuvo resultados más favorables a los trabajadores viñamarinos, especialmente a los de la Refinería de Azúcar, logrando obtener las reivindicaciones que los habían llevado a paralizar la industria $^{18}$, mientras que, en el puerto, especialmente los ferroviarios, quienes habían iniciado la movilización, no lograron obtener sus demandas. En esta misma lógica, probablemente los dirigentes más golpeados en la zona hayan sido los anarquistas, quienes dirigieron las movilizaciones, dejándole una posibilidad a los socialistas de avanzar en el mundo obrero de la zona, especialmente en Viña del Mar, dado el éxito en la CRAV. Este triunfo a medias, en que no todos los trabajadores participes, sumado a al repliegue de los anarquistas, explicaría en parte, que al año siguiente los socialistas hayan creado un comité de propaganda, base para la creación de la sección viñamarina del partido.

Sin embargo, sus primeros intentos organizativos se desplegaron en la acción "fuera" de la fábrica. Rápidamente en Valparaíso hacia el final de la movilización, los socialistas fundan un periódico propio, La Defensa Obrera ${ }^{19}$. Pero a la vez iniciaron su enraizamiento social en la ciudad vecina, al formar en Viña del Mar la organización de la Gran Federación de Gremios en la localidad, mientras colaboraba en la creación de la Sociedad de Oficios Varios, la cual tenía como objetivo reunir en una sola sociedad de resistencia "a todos los trabajadores no asociados o que deseen pertenecer al amparo de su estandarte de redención social" 20 . El principal referente del intento por construir tejido social en Viña del Mar fue Ramón Sepúlveda Leal, cercano a Luis Emilio Recabarren y como ya se mencionó, un activo dirigente de la naciente colectividad durante la "Huelga del Mono". En esta ciudad, entre los años 1913 y hasta finales de 1914, Sepúlveda Leal se encargó de fortalecer la sociedad de resistencia, organizar el mundo del trabajo femenino e intentar insertarse en las organizaciones sindicales, mientras que la acción más propiamente político-partidaria, por ese entonces, la realizaban en Valparaíso, al militar aún en la

\footnotetext{
${ }^{15}$ Ortiz, op.cit., p. 246

${ }^{16}$ Para un análisis en detalle de esta huelga, ver Eduardo Godoy, La Huelga del Mono. Los anarquistas y las movilizaciones contra el retrato obligatorio (Valparaíso, 1913), Santiago de Chile, Quimantú, 2014.

${ }^{17}$ Navarro, op.cit., p. 50; p.52.

${ }^{18}$ Godoy, op.cit., p.174.

${ }^{19}$ Ibid, p. 54.

${ }^{20}$ La Defensa Obrera, Valparaíso, 22 de noviembre de 1913, p.4.
} 
agrupación porteña. También Sepúlveda Leal fue un activo corresponsal y columnista de La Defensa Obrera ${ }^{21}$, periódico oficial del POS en la zona. Por tanto, al menos por casi un año Ramón Sepúlveda Leal, junto con otros militantes participaron en la agrupación porteña ${ }^{22}$, mientras que su trabajo sindical y social lo desarrollaban en el vecino balneario.

Fue en el 4 de noviembre de 1914 cuando Ramón Sepúlveda Leal, Carlos Orrego y Carlos Flores convocaron a un grupo de trabajadores y militantes para "que el trabajador se instruyera, para que conociera el socialismo en sus diferentes fases y así pudiera formarse una conciencia definida para la defensa de sus intereses" ${ }^{23}$. Esta será la fecha de inicio de la sección Socialista en la ciudad, conmemorándose todos los años a través de un paseo campestre $^{24}$.

La autonomía de la sección porteña les permitió a los socialistas viñamarino abocarse en la inserción en las fábricas, a través de la creación de una serie de organizaciones. Al parecer, solo un puñado de trabajadores de la ciudad integraron la Sociedad de Oficios Varios anteriormente señaladas, ya que en el periódico La Defensa Obrera hizo un llamado en el mes de noviembre de 1913 en donde señalaban que "si los hombres no tienen el valor ni perseverancia para defender sus intereses, que les den el ejemplo las compañeras mujeres!" 25 . Lo mismo ocurría con los obreros del puerto Las Salinas, los cuales se encontraban en una franca desorganización ${ }^{26}$.

A través de conferencias dirigidas a los obreros, se esperaba atraer mayor contingente y engrosar sus filas ${ }^{27}$, dando cabida a miembros ajenos al socialismo, como se comprueba en la segunda conferencia de esta organización, en donde disertó Pedro Ortuzar, miembro de la FORCh ${ }^{28}$. A lo anterior se sumaba la difusión del ideal socialista a través de la distribución periódico La Defensa Obrera, superando numéricamente a la vecina sección del puerto a finales de $1913^{29}$, siendo una auspiciosa señal de la importancia que llegará a tener la sección viñamarina.

El 17 de agosto de 1914 se llevó a cabo un mitin, organizado por las sociedades de resistencia de Viña del Mar en el centro de la ciudad, la plaza Francisco Vergara, en contra de la carestía de la vida. Los socialistas volvieron a tener una fuerte presencia, siendo Sepúlveda quien abriera y cerrara el comicio, seguido por Roa Medina, redactor de La Defensa Obrera, para posteriormente hablar Carlos Flores, otro destacado dirigente socialista de Viña del Mar, logrando una concurrencia de cerca de dos mil obreros ${ }^{30}$. Al año siguiente, la Sociedad de Resistencia de Oficios Varios cambió su nombre en Federación de Oficios Varios. A pesar de no haber encontrado información sobre las razones del cambio,

\footnotetext{
${ }^{21}$ Riquelme, op. cit., p. 44.

22 Grez, op. cit., p. 48.

${ }^{23}$ La Defensa Obrera, Valparaíso, 7 de noviembre de 1914, p.3.

${ }^{24}$ La Comuna, Viña del Mar 29 de noviembre de 1919. Se hace el llamado para la conmemorar el quinto aniversario de propaganda socialista en la ciudad. La "fiesta" se llevó a cabo en el Parque Lusitania en Chorrillo.

${ }^{25}$ La Defensa Obrera, Valparaíso, 22 de noviembre de 1913, p.4.

26 Ídem.

${ }^{27}$ La Defensa Obrera, Valparaíso, sábado 6 de diciembre de 1913, p.4.

${ }^{28}$ La Defensa Obrera, Valparaíso, sábado 17 de enero de 1914, p.4.

${ }^{29}$ La Defensa Obrera, Valparaíso, sábado 13 de diciembre de 1913, p.2.

${ }^{30}$ La Defensa Obrera, Valparaíso, sábado 22 de agosto de 1914
} 
podemos señalar que la presencia socialista en ella se demuestra con mayor fuerza, toda vez que en septiembre de 1915 la Federación comenzó a funcionar en el mismo local que lo hacia el POS $^{31}$.

Hacia el mes de octubre del mismo año, los socialistas comenzaron a realizar una serie de conferencias frente a la Refinería de Azúcar, con el objetivo de educar y organizar a los trabajadores de esta importante industria ${ }^{32}$. Estas conferencias tuvieron positivos resultados, toda vez que, a principios de noviembre, cerca de cincuenta trabajadores de esta industria decidieron formar una "sociedad de defensa del trabajo" "33. Esta organización será la base de la Unión y Defensa del Trabajo (UyDT), entidad obrera creada un año exacto después de la fundación de la sección del POS en Viña del Mary fue la más relevante de la ciudad durante la etapa de crecimiento e inserción, al reunir en su seno a los trabajadores de las principales industrias de la ciudad, en donde los trabajadores de la CRAV jugaron un rol fundamental para el mantenimiento de esta. Analizando sus estatutos, se le puede calificar como una sociedad de resistencia, ya que no solo abogaba por la "transformación social, es decir [...] un régimen colectivo en reemplazo del régimen individual capitalista" 34 ,sino que también de ayuda a los asociados en momentos de crisis. La influencia de los socialistas se conservó presente en este nuevo organismo y esto se verifica al constatar que la UyDT, al igual que la Federación de Oficios Varios en su momento, funcionaba en el mismo centro que el POS $^{35}$. Sin embargo, la UyDT iría más allá, aportando los elementos necesarios para la instalación de una biblioteca que funcionaba en el espacio ${ }^{36}$. La influencia socialista queda clarificada aún más al analizar los cargos directivos alcanzados por militantes del POS, como por ejemplo "los obreros Carlos Flores U. y Manuel Leiva S. secretario general y de actas"37 en 1916.

Hacia mediados de 1916, la UyDT convocó a una manifestación en contra de las autoridades municipales, dado el retraso en obras públicas, las cuales contaban con un empréstito otorgado por el gobierno equivalente a 32 mil 500 libras esterlinas. Según el llamado que hacían los socialistas, el objetivo era: "que las obras proyectadas se lleven a cabo por administración fiscal, llenando así dos objetivos que interesan al pueblo: el saneamiento de la ciudad y dar trabajo a gran número de desocupados" 38 . En la siguiente sesión municipal, lo solicitud de la UyDT fue tratado, comprometiéndose a reanudar los trabajos en una de las principales calles de la ciudad, así como nombrar una comisión para la construcción de un Matadero Público ${ }^{39}$, demostrando que la Unión y Defensa del Trabajo cobraba cada vez más relevancia no solo en el movimiento obrero local, sino que también en el plano político-institucional, toda vez que logró influir en la agenda pública del gobierno local, reponiendo el asunto del empréstito y los trabajos públicos que debían

\footnotetext{
${ }^{31}$ El Socialista, Valparaíso, sábado 28 de agosto de 1915, p.4.

${ }^{32}$ El Socialista, Valparaíso, sábado 9 de octubre de 1915, p.4.

${ }^{33}$ El Socialista, Valparaíso, sábado 6 de noviembre de 1915, p.4.

${ }^{34}$ El Socialista, Valparaíso, sábado 16 de junio de 1916, p.4.

${ }^{35}$ El Socialista, Valparaíso, sábado 20 de noviembre de 1915, p.1.

${ }^{36}$ El Socialista, Valparaíso, sábado 25 de marzo de 1916, p.4.

${ }^{37}$ El Socialista, Valparaíso, sábado 1 de julio de 1916, p.4.

${ }^{38}$ El Socialista, Valparaíso, sábado 8 de julio de 1916, p.2.

${ }^{39}$ El Socialista, Valparaíso, sábado 29 de julio de 1916, p.4.
} 
hacerse con ese dinero. En agosto de 1916, la municipalidad reconoció a la UyDT como un ente válido al contestar de manera formal y positiva al pliego emanado de la organización obrera que exigía el cumplimento de las obras:

A indicación de los regidores señores, Eleodoro Ramírez y Guillermo Mayor, la Corporación acordó por unanimidad (ilegible) dicha comunicación, haciendo presente a esa Sociedad que la Municipalidad está sumida de los mejores propósitos en orden al cumplimiento de la Ley de Empréstito que consultó fondos especiales para la ejecución de diversas obras públicas en esta ciudad ${ }^{40}$.

$\mathrm{Y}$ a pesar de que los trabajos mostraron una clara demora ${ }^{41}$, la cita anterior es llamativa, ya que las autoridades dieron respuesta a una organización obrera en un periodo en donde lo común era ignorar las demandas de la clase trabajadora o reprimirlas de forma violenta. A nuestro parecer, la actitud de las autoridades municipales se debe no solo a la relevancia que estaba adquiriendo la UyDT, sino que también a una preocupación de parte de la oligarquía viñamarina ante la arremetida de los trabajadores en la ciudad, que sin embargo no era del todo rupturista y buscaba soluciones de corte institucional.

Finalizando el mes de octubre de 1916, los obreros de la cantera "Álamo" realizaron las gestiones para incorporarse en la UyDT luego de una serie de conferencias realizadas por la misma ${ }^{42}$, demostrando así la efectividad de este tipo de propaganda. Tras un bienio de los primeros pasos del POS en Viña, Manuel Leiva escribía:

Hoy, después de dos años de tesonera y constante lucha en pro del desenvolvimiento del principio del programa socialista, nos sentimos con mayor fuerza y fe para seguir luchando, porque con nuestras armas que son la razón y la justicia, tenemos la convicción que no está lejano el día en que ha de alumbrar el sol del socialismo el camino de la redención humana"43.

Sin embargo, Carlos Flores fue más prudente en su balance. El 18 de noviembre se publicaba un artículo de su autoría en donde señalaba:

Compañeros: al terminar la jornada de dos años si ella ha sido progresista no es menos cierto que estamos muy lejos de nuestro primer triunfo y primera etapa, necesitamos organizar la gran falange de productores para conquistar mejoras económicas y sociales para el presente y el porvenir. ${ }^{44}$

El tiempo le daría razón a la prudencia de Flores, ya que en mayo de 1917, un artículo publicado en El Socialista realizaba una serie de reprimendas a los y las trabajadores de la localidad por no organizarse e incluso, en el caso de la Refinería llamaba a los obreros a "darle vida a la institución que han ido abandonado poco a poco, que es la

${ }^{40}$ El Socialista, Valparaíso, sábado 20 de agosto de 1916, p.4.

${ }^{42}$ El Socialista, Valparaíso, sábado 28 de octubre de 1916, p.4.

${ }^{43}$ El Socialista, Valparaíso, sábado 4 de noviembre 1916, p.3

${ }^{44}$ El Socialista, Valparaíso, sábado 18 de noviembre de 1916, p.3. 
Unión y Defensa del Trabajo"45. En el mismo artículo, repasaba la desorganización de los trabajadores de otros gremios, tales como carpinteros y textileros por su "apatía y la indiferencia malsana en que permanecen". El llamado era a unirse para levantar una antigua institución de la ciudad, la Federación Obrera Local (FOL), la cual había sido creada por los anarquistas de la ciudad como sección viñamarina de la FORCh y que había agrupado a importantes sectores obreros de Viña del Mar $^{46}$. La presencia libertaria en la ciudad se mantuvo durante estos años, incluso en la UyDT, lo que se confirmaría con la publicación realizada en el socialista, donde se indicaba que, en una de las sesiones últimas de la sección fábrica de Soda en donde

se han presentado tres compañeros que porque se han puesto el letrero de antipolíticos, (mientras no hay elección) se creen con derecho para ir a engañar al trabajador con falso espíritu de apostolado... Olvidan los que así obran, que por encima de escuelas anárquicas o apolíticas, está la unión de todos los trabajadores sean estos del color que sean, para defenderse de la tiranía capitalista ${ }^{47}$.

A pesar de que los socialistas fueron ganado cada vez más terreno en el mundo obrero y popular de la ciudad, los ácratas no desaparecieron del todo, ya que existe el registro de que en 1920 se fundó una sección de la IWW en Viña del Mar, pero fue opacada por la hegemonía de los socialistas ${ }^{48}$.

Ahora bien, la idea de refundar la FOL había comenzado a resurgir entre los miembros del Comité Pro $1^{\circ}$ de $\mathrm{Mayo}^{49}$. Las organizaciones que recompusieron esta Federación fueron Unión General de Trabajadores, Unión y Defensa del Trabajo, Federación de Carpinteros y Partido Obrero Socialista, demostrando así que el intento de los socialistas viñamarinos por que confluyera el sindicalismo con la política partidaria es anterior a lo que ocurrirá posterior a 1919 con la FOCh, en donde, no existió una clara definición entre partido y la central obrera, toda vez que dirigentes socialista (y posteriormente comunistas) ocuparon importantes cargos dentro de la central de trabajadores y esta última siguió por muchos años los lineamientos de aquellos partidos.

La lucha por unificar a las organizaciones viñamarinas bajo el alero de una sola institución fue bastante compleja, o por lo menos eso se deduce de los artículos publicados a las pocas semanas de la fundación de dicha federación:

Se hace necesario que las organizaciones obreras de esta localidad le presten más atención a la Federación Local, encargando a sus delegados asistan a las reuniones de

\footnotetext{
${ }^{45}$ El Socialista, Valparaíso, jueves 17 de mayo de 1917, p.2.

${ }^{46}$ Para febrero de 1914, la FOL estaba integrada por las Sociedades de Resistencia de Panaderos, Federación de Carpinteros, Federación de Pintores, Oficios Varios, Hojalateros y Estucadores, Operarios Fábrica de Azúcar, El Despertar de la Mujer, Operarios Aceites Vegetales, Comerciantes Ambulantes, Fábricas Unidas, Sección Victoria y Caleta Abarca, La Batalla, Santiago, 2a quincena de febrero, 1914, p. 2-3. Para más detalles sobre los anarquistas en Viña del Mar, revisar la obra de Sergio Grez, Los anarquistas y el movimiento obrero: la alborada de "la Idea" en Chile, 1893-1915, en especial, el capítulo IX.

${ }^{47}$ El Socialista, Valparaíso, sábado 10 de noviembre de 1917, p. 4.

${ }^{48}$ El 29 de enero de 1920, Ramón Sepúlveda Leal publica un artículo contra los miembros de la I.W.W local, titulado "Los Y.W.W y los seudos anarquistas", La Comuna, 20 de enero de 1920

${ }^{49}$ El Socialista, Valparaíso, jueves 4 de mayo de 1917, p. 2.
} 
este cuerpo representativo de las sociedades de lucha económica y moral. No es posible que se deje morir una entidad que recién nace a la lucha con fines altamente emancipadores de la clase productora. Es necesario prestarle más atención, tomarle el peso a la responsabilidad moral que recaerá sobre los que huyen dejando que una institución de la naturaleza de la Federación Local desaparezca. Más actividad y menos indiferentismo. No se diga más tarde que la Federación nació muerta." 50

A pesar de dicho traspiés, la Unión y Defensa del Trabajo siguió con sus actividades, eligiéndose un nuevo directorio el 4 de julio, cuyo cargo de secretario general recayó en el socialista Manuel Leiva ${ }^{51}$. En la huelga de lancheros de 1917 acontecida en Valparaíso, la UyDT participó activamente difundiendo cerca de 4.000 proclamas, según la información de la prensa ${ }^{52}$. Esta organización fue sumando nuevas instituciones fabriles durante ese año: Fábrica de Soda y Fábrica de Aceite, así como la sección de Ambos Sexos de una empresa textil que no se identifica ${ }^{53}$. El objetivo de organizar a estas industrias fue para "la verdadera emancipación económica y social" como lo expuso Carlos Flores en $E l$ Socialista, en donde hizo un llamado a las nuevos trabajadores y trabajadoras para que perseverarán "en la lectura de periódicos y folletos obreros que oriente la conciencia popular al verdadero campo de la lucha de clase, para no caer en el desgraciado servilismo y esclavitud, que algunos aceptan por ignorancia y otros por cobardía o adulación a sus amos." 54 Al poco tiempo, la sección Textiles de Ambos Sexos, llevó a cabo su primera actividad como miembro de la UyDT realizando a cabo una colecta a beneficio de Rosa Montenegro, trabajadora que fue despedida de la fábrica ${ }^{55}$.

Hacia septiembre de 1917, la Sociedad Unión y Defensa del Trabajo estaba compuesta por cuatro secciones: oficios varios, fábrica de aceites, textiles y fábrica de soda demostrando así que la influencia socialista comenzaba a repuntar considerablemente. Si a esto le sumamos las organizaciones obreras que no integraban la UyDT, pero estaban influenciada por los socialistas, como la Federación de Carpinteros y Ramos Similares, las cuales funcionaban todos los domingos en el Centro Obrero de los socialistas viñamarinos $^{56}$, podemos considerar que la inserción del POS en el movimiento obrero comenzaba a tomar cuerpo.

Durante esta etapa, los socialistas participaron en sus primeras elecciones parlamentarias que se realizaron a principios del año 1915, llevando como candidato a senador a Tránsito Salinas y a diputado a Víctor Roa Media ${ }^{57}$, obteniendo magros resultados. Aunque las agrupaciones socialistas intentaban avanzar, su despliegue era aún lento, incipiente y fragmentario, lo que se reflejó en los resultados electorales de 1915; de allí que durante ese año se buscó superar lo que Sergio Grez ha llamado la "dispersión

${ }^{50}$ El Socialista, Valparaíso, jueves 7 de junio de 1917, p.2.

${ }^{51}$ El Socialista, Valparaíso, sábado 5 de julio de 1917, p.2.

${ }^{52}$ El Socialista, Valparaíso, sábado 18 de agosto de 1917, p.1.

${ }^{53}$ El Socialista, Valparaíso, sábado 1 de septiembre de 1917, p.1.

${ }^{54}$ El Socialista, Valparaíso, sábado 8 de septiembre de 1917, p.1.

${ }^{55}$ El Socialista, Valparaíso, sábado 15 de septiembre de 1917, p.1.

${ }^{56}$ El Socialista, Valparaíso, sábado 29 de septiembre de 1917, p.4.

${ }^{57}$ La Defensa Obrera, Valparaíso, 27 de febrero de 1915. 
inicial", para lo cual se realizó el primer Congreso partidario en Santiago, en la significativa fecha del $1^{\circ}$ de mayo. En el evento, se planteó un Estatuto, principios y programa de la colectividad, cuyos lineamientos más destacados fueron que, internamente todas las secciones debían informar cada mes a la estructura nacional de la colectividad y contribuir con una cuota para el funcionamiento de la organización y su nuevo periódico "nacional", El Socialista; por otro lado, más allá de los principios ideológicos articulados en torno a la lucha de clases, el carácter obrero de la organización y la búsqueda del socialismo a través de la organización cooperativa de la sociedad, el Congreso articuló sus principales ejes de acción en torno al mejoramiento político, económico y educacional de los trabajadores.

Tres definiciones son destacables de este Congreso: primero, la adopción definitiva de todas las secciones del nombre Partido Obrero Socialista, que había sido hasta entonces la denominación de la agrupación tarapaqueña, siendo otra evidencia de la influencia que tuvieron los socialistas norteños en la instancia, en la cual fue representada por Luis Emilio Recabarren. Junto a este intento por homogeneizar a la colectividad a escala nacional, se tomó una segunda definición a destacar, la constitución del Comité Ejecutivo Nacional $(\mathrm{CEN})$. Este, en el marco de la división existente en la sección santiaguina ${ }^{58}$, se decidió que estuviese radicado por un año en Valparaíso (periodo que se extendió más de lo estipulado) y compuesto por militantes de esa zona. De esta manera, la primera directiva del POS estuvo encabezada por tres socialistas porteños y dos viñamarinos, recayendo la Secretaría General de la organización en Ramón Sepúlveda Leal. Esto último, además de la división en Santiago y de ser la segunda zona más relevante del corazón político de la república, demuestra la valoración que tenían Sepúlveda Leal entre sus pares. De allí que no fuera extraño que por estos años el militante socialista de Viña del Mar juegue un papel orgánico crecientemente importante. El último punto por destacar fue que Recabarren inició una gira por todo el país para difundir el "ideal socialista" en las otras secciones de la colectividad. Estos fueron los años que Recabarren y otros dirigentes, entre ellos Manuel Roa y Sepúlveda Leal $^{59}$, se desplazaron para fortalecer o crear secciones en distintas zonas que se consideraban relevantes o estaban debilitadas. Ante el panorama crítico de la agrupación santiaguina, la radicación del CEN en Valparaíso y la importancia que tenía esta última, no es de extrañar que Recabarren haya iniciado su periplo con una estadía en la sección porteña.

Diferenciandose de la mayoría de las secciones, una que acató más activamente las resoluciones del Congreso de 1915 fue la de Viña del Mar, siendo de las pocas que cumplió periódicamente con el envío de información y cuotas al CEN desde $1915^{60}$. A esto,

\footnotetext{
${ }^{58}$ El conflicto suscitado en Santiago se debió a la crítica de un grupo de socialistas entre los que se encontraba Luis Zuloaga, presidente de la sección santiaguina, Miguel Silva y Luis Perujo, quienes cuestionaron la labor al interior del municipio de Manuel Hidalgo. Los acusadores señalaban que este último se había alejado de las líneas del partido y había realizado algunas alianzas al interior del municipio con el Partido Democrático. Por su parte, el grupo "hidalguista" señalaba que todo el conflicto se debía a que, una vez llegado Manuel Hidalgo al municipio, no había entregado cargos municipales al grupo anti-hidalguista.

59 El primero se radicaría un tiempo en Taltal, donde levantaría una sección socialista; mientras que Sepúlveda Leal partiría en 1916 a Concepción, donde tuvo escasos resultados en su objetivo propagandístico; El Socialista, Valparaíso, 11 de marzo de 1916.

${ }^{60}$ Grez (b), op. cit., p.51.
} 
podemos sumar que, Viña del Mar, comparativamente, era una de las secciones donde más ejemplares de El Socialista se vendían, sin contar la modalidad de suscripción, tal como se puede ver en el cuadro $\mathrm{n}^{\circ} 1$.

\section{CUADRO $N^{\circ} 1$}

COMPARACIÓN DE LAS VENTAS DEL PERIÓDICO EL SOCIALISTAEN LAS CIUDADES DE VIÑA DEL MAR Y VALPARAISO, SEGUNDO SEMESTRE DE 1916**

\begin{tabular}{lcc}
\hline Mes & Viria del Mar & Valparaiso \\
\hline Júio & $\$ 44,55$ & $\$ 22,55$ \\
Agosto & $\$ 54,70$ & $\$ 28,70$ \\
Septiembre & $\$ 61,00$ & $\$ 36,40$ \\
Octubre & $\$ 45,00$ & $\$ 21,40$ \\
Noviembre & $\$ 54,40$ & $\$ 12,40$ \\
Diciembre & $\$ 50,50$ & $\$ 36,40$ \\
\hline Total & $\$ 310,15$ & $\$ 157,85$ \\
\hline
\end{tabular}

Fuerte: El Socialista 16 de diciembre de 1916,23 de diciembre de 1916, 30 de diciemb de 1916 y 4 de enero de 1917.

Al llegar al año 1917, es posible señalar que los socialistas viñamarinos habían logrado una importante inserción en las principales industrias de la ciudad a través de la UyDT, lo que le permitía tener una injerencia a nivel local de considerable relevancia, lo que se demostró principalmente con el conflicto del empréstito y con el aumento de trabajadores y trabajadoras de las distintas ramas industriales que existían en la ciudad que se sumaron a esta sociedad. Esta posición estratégica será aprovechada por el POS para agudizar la relación entre obreros y patrones, desarrollándose en el siguiente periodo una serie de huelgas lideradas por los trabajadores de las industrias en donde los socialistas poseían una fuerte presencia, principalmente los refineros y los textileros. Sin embargo, tanto una publicación propia como lograr un buen resultado en las elecciones estaban al debe. Estos déficits se irán subsanado en los siguientes años.

\section{3.-El camino hacia consolidación del POS en Viña del Mar: prensa obrera, huelgas y elección municipal: 1918-1922}

1918 fue año de elecciones municipales y parlamentarias. Estando insertos y con una fuerza en crecimiento en el mundo proletario, el POS decidió llevar a Sepúlveda Leal como candidato a diputado por la provincia de Valparaíso, mientras que al municipio de Viña del Mar fue Carlos Flores el elegido. Sin embargo, su inserción en el mundo

\footnotetext{
** Se analizan solamente las ventas y no las suscripciones, debido a que El Socialista informó que la sección de Valparaíso adeudaba un monto de \$95.60 en suscripciones del periódico. El Socialista, Valparaíso, 11 de enero de 1917.
} 
proletario no fue garantía de triunfo, como reflejaron los resultados. La derrota de Ramón Sepúlveda Leal sirvió de aprendizaje para futuras elecciones ya que, al comparar los resultados de Sepúlveda con los del candidato municipal Carlos Flores, el POS viñamarino vio en la municipalidad una opción alcanzable, por lo que se propuso trabajar en ello para poder lograr un cupo municipal en las siguientes elecciones ${ }^{61}$. Esto, tal como señala Navarro, "por desarrollarse en espacios más pequeños, las campañas municipales resultaban más accesibles, teniendo en cuenta los escasos recursos económicos con que el partido disponía. Además, al involucrar temas cotidianos y problemas locales, el municipio era más cercano a la realidad de los trabajadores"

Los años que transcurren entre 1918 a 1922 son de un extenso desarrollo en el movimiento obrero a nivel nacional, no solo por la extensión de este, que abarcó gran parte de las zonas urbanas del país, sino que también por el nivel de movilización alcanzados. Las consecuencias de la Primera Guerra Mundial se hicieron sentir con fuerza y la escasez de alimentos, el aumento de la cesantía y la disminución de los salarios desembocaron en jornadas de movilizaciones que dieron origen en Santiago, a una organización multisectorial impulsada por uno de los consejos federales de la FOCh, la Asamblea Obrera de Alimentación Nacional (AOAN). Esta se encargó de coordinar en distintas ciudades huelgas y jornadas de movilizaciones demandando que el Estado se hiciera cargo de la crisis que vivía el país, proponiendo medidas como la supresión del impuesto al ganado extranjero, limitar la exportación de alimentos como los cereales y la colonización de tierras en el sur del país, entre otras medidas ${ }^{63}$. Con una composición heterogénea, la AOAN evidenció la posibilidad de una coexistencia entre demócratas, anarcosindicalistas y socialistas en el mundo popular y obrero chileno.

Viña del Mar no fue ajeno a este movimiento y la sección Viña del Mar de la AOAN fue fundada a finales del mes de mayo de 1919 y tuvo como base las mismas organizaciones que compusieron el Comité Pro $1^{\circ}$ de Mayo de ese año: Unión de Albañiles y Estucadores en Resistencia, Federación de Carpinteros y Ramos Similares, Unión Fabril de O. Varios, Consejo Federal $\mathbf{n}^{\mathbf{0}} 1$ de la FOCh y el Centro de Propaganda Socialista, siendo la primera reunión dirigida por Manuel Leiva ${ }^{64}$. Ya con unos meses de funcionamiento, se puede corroborar una presencia más firme de los socialistas viñamarinos en la AOAN, como es el caso del mitin realizado el día 28 de julio, en donde tomaron la palabra destacados dirigentes socialistas entre ellos Carlos Flores, E. Gonzales y Manuel Leiva ${ }^{65}$.

Es en este contexto a nivel nacional en que se inscribe el periodo de consolidación del POS en Viña del Mar, el cual se puede datar entre los años 1918 a 1922. Las movilizaciones organizadas por el comité local de la $\mathrm{AOAN}^{66}$ les permitió a los socialistas ampliar el espectro al que iba dirigido sus discursos, los que principalmente eran los trabajadores industriales. A través de la AOAN pudieron llegar a arrendatarios

\footnotetext{
${ }^{61}$ A pesar de haber sacado solo 48 votos, Carlos Flores logró aumentar en 24 desde la última elección.

${ }^{62}$ Navarro, op.cit., p. 198.

${ }^{63}$ Ignacio Rodríguez, Protestas y Soberanía Popular: Las Marchas del Hambre en Santiago de Chile 19181919, Tesis para optar al grado de Licenciado en Historia, PUCV, p. 48.

${ }^{64}$ La Comuna, Viña del Mar, 31 de mayo de 1919, p.4.

${ }^{65}$ La Comuna, Viña del Mar, 2 de agosto de 1919, p.3.
} 
empobrecidos, cesantes y personas que atravesaban alguna carencia en sus necesidades básicas. Lo anterior, junto a las experiencias propias del POS acumuladas de los años previos, permitieron aumentar la inserción de sus militantes en el mundo obrero de la ciudad, cuestión que le fue propicio para hegemonizar el movimiento obrero local, a diferencia de lo que sucedía en otras ciudades de la zona central, donde el POS aun disputaba en equilibrio de fuerzas el liderazgo con las corrientes anarquistas o demócratas.

Esta hegemonía se tradujo, en la creación del periódico La Comuna, el cual tuvo circulación entre 1919 y 1921. El devenir de este órgano periodístico no es menor, pues en el marco comparativo de los distintos periódicos de la colectividad durante las dos primeras décadas, es uno de los con mayor duración, regularidad y números de entre los periódicos publicados por los socialistas en la zona central del país, tal como se puede apreciar en el cuadro $\mathrm{n}^{\circ} 2$.

\section{CUADRO N²}

DURACION DE PERIODICOS SOCIALISTAS PUBLICADOS EN VALPARAÍSO, VIÑA DEL MAR Y SANTIAGO

\begin{tabular}{lcccc}
\hline $\begin{array}{l}\text { Nombre } \\
\text { Periodico }\end{array}$ & $\begin{array}{c}\text { Primera } \\
\text { publicación }\end{array}$ & $\begin{array}{c}\text { Ultima } \\
\text { publicación }\end{array}$ & $\begin{array}{c}\text { Tiempo de } \\
\text { publicación } \\
\text { (en meses)* }\end{array}$ & $\begin{array}{c}\mathrm{N}^{\circ} \mathrm{de} \\
\text { Publicaciones }\end{array}$ \\
\hline La Defensa Obrera & 1913 & 1915 & 17 & 63 \\
El Socialista & 1915 & 1918 & 35 & 127 \\
Acción Obrera & 1916 & 1916 & 4 & 5 \\
La Bandera Roja & 1919 & 1919 & $\mathbf{5}$ & 8 \\
La Comuna & $\mathbf{1 9 1 9}$ & $\mathbf{1 9 2 1}$ & $\mathbf{2 8}$ & $\mathbf{1 5 2}$ \\
\hline Promedio & & & 17,8 & 71 \\
\hline
\end{tabular}

Fuente: Osvaldo Arias, La Prensa Obrera en Chile, Chillán, Servicio Central de Extensión y Acción Social Oficina de Difusión y Publicaciones, Universidad de Chile Chillán, 1970

La importancia de La Comuna no solo radica en las cifras anteriormente señaladas, sino que, como lo señala la historiadora colombiana Luz Núñez:

el periódico no sólo funcionaba como medio de comunicación, en el sentido más clásico de llevar el mensaje a un receptor, sino que en torno a él se tejía una serie de relaciones sociales y políticas, que ayudaba a reforzar los objetivos de la publicación y que, además, se extendía en un radio de acción mucho más amplio: el perteneciente a la 
cultura política y, especialmente, a los modos y espacios de sociabilidad política y popular ${ }^{67}$.

Esta sociabilidad que generaban los periódicos obreros populares (como los denomina la autora) se tradujo en una serie de conferencias y jornadas (abiertas al público y orientadas a los obreros y obreras) llevadas a cabo en el mismo espacio en donde funcionaba el periódico, como fue el caso de La Comuna. A esto hay que agregar que también funcionaba el Cuadro Dramático Carlos Marx, quizás la expresión teatral-obrera vinculada al socialismo más relevante de la provincia durante el periodo ${ }^{68}$. A lo anterior, se suma la biblioteca, la cual, como ya se ha visto, fue apoyada fuertemente por la UyDT desde que esa organización se fundó. A pesar de que estos elementos no son una característica propia de los periódicos obreros de Chile, ya que se les puede encontrar en otras latitudes, si es importante destacarlo, toda vez que demuestra la relevancia que tuvo La Comuna en cumplir los objetivos de inserción y difusión de la cultura política socialista en el mundo obrero.

La Comuna estuvo inicialmente dirigido por Ernesto González y Manuel Leiva, ya que Ramón Sepúlveda se encontraba en otra zona del país durante las primeras ediciones, pero al volver, quedó a cargo del periódico. Aunque nunca logró convertirse en un diario obrero, como era el objetivo de los editores, dadas las dificultades económicas para subsistir, alcanzó a tener un tiraje bisemanal y de interdiario, apareciendo martes, jueves y sábados durante un breve lapso, cuestión que lo diferencia de cualquier otro medio periódico socialista de la época, al menos en la zona central del país, a excepción de $L a$ Federación Obrera ${ }^{69}$. El contenido mezcló temas nacionales vinculados a la política del POS y la FOCh, siendo el medio oficial de ambas organizaciones, los planteamientos ideológicos que difundían (a través de entrevistas, columnas de opinión y declaraciones) y temas locales, entre ellos las movilizaciones y sociabilidad obrera y también algunos temas locales, como críticas a la gestión municipal ${ }^{70}$ y otros hechos de connotación criminal ${ }^{71}$. Al igual que lo sucedido por estos años en Tarapacá, Antofagasta ${ }^{72}$ y Punta Arenas $^{73}$, el taller de La Comuna fue allanado, destruido y se sustrajeron piezas esenciales para su funcionamiento, todo esto por la fuerza policial luego de un incidente con un grupo de manifestantes compuesto de "personas decentes" a favor de la patria ${ }^{74}$, en el contexto del

\footnotetext{
${ }^{67}$ Luz Núñez, El Obrero Ilustrado. Prensa obrera y popular en Colombia. 1909-1929, Bogotá D.C, Ediciones UniAndes, 2006, p.45-46

${ }^{68}$ Este cuadro dramático, compuesto integrantemente por obreros y obreras y sus familiares, fue fundado por los socialistas en una fecha indeterminada entre 1914 y 1915. Luego de la caída de la dictadura de Carlos Ibáñez del Campo, fue reorganizado por la sección viñamarina del PCCh, siendo uno de sus integrantes, Carlos Segundo Flores, hijo del dirigente del mismo nombre.

${ }^{69}$ La Federación Obrera fue el diario oficial de la FOCh durante los años 1922 y 1924, fecha en que cambia de nombre a Justicia.

${ }^{70}$ La Comuna, Viña del Mar, 24 de mayo de 1919, p.3.

${ }^{71}$ La Comuna, Viña de Mar, 14 de junio de 1919, p.3.

72 Karen Donoso, Las mordazas a la prensa obrera. Los mecanismos de la censura política en Chile, 19191925, Izquierdas, $n^{\circ} 28$, julio 2016, p. 204, 205.

${ }^{73}$ La Comuna, Viña del Mar, 4 de septiembre de 1920, p.2; La Comuna, Viña del Mar, 11 de septiembre de 1920, p.1; La Comuna, Viña del Mar, 17 de septiembre de 1920, p.2.

${ }^{74}$ La Comuna, Viña del Mar, 4 de septiembre de 1920, p.1.
} 
ficticio enfrentamiento bélico contra Perú, conocida como la "Guerra de don Ladislao"75. Las razones del ataque, según el periódico, fueron el aprovechamiento del patriotismo para "vengarse de nosotros", al ser "un peligro para politiqueros relajados y para explotadores y vividores desvergonzados"76.

El periódico cerró en agosto de 1921 tras la llegada de Recabarren a Santiago y la refundación del diario La Federación Obrera, probablemente concibiéndose como innecesario mantener la publicación en una ciudad tan cercana a la capital del país y con un diario que pretendía ser de un alcance nacional. A pesar de que hay indicios de que se intentó continuar con el periódico en formato diario ${ }^{77}$, todo indica que esto no sucedió. De todas formas, el despliegue de La Comuna es expresión de la creciente presencia de los socialistas en Viña del Mar, lo cual vendría aparejado del desarrollo cada vez más influyente en otras dimensiones de la acción política obrera de la ciudad.

La inserción en el movimiento obrero por parte de los socialistas durante esta etapa fue mayor que en los años anteriores, denotando una consolidación de la misma. También fueron mayores las huelgas, dado que tal como lo ha plantea el mismo DeShazo, la acción sindical en estos años fue importante ya que "el número de huelgas que tuvo lugar en este periodo sobrepasó por mucho al de 1905-1907, y 1919 probó ser el año más propenso a la huelga en la historia de Chile, hasta los años cincuenta."78. Viña del Mar no estuvo ajeno a esta tendencia y las paralizaciones de las industrias por parte de los trabajadores fueron recurrentes entre 1919 y 1922, siendo gran partes de ellas dirigidas por los socialistas. Esto se debió principalmente a dos factores: a) en el plano local, la experiencia acumulada por parte de los socialistas viñamarinos en organizaciones como la UyDT y la AOAN local y b) en el plano nacional, la hegemonía alcanzada por los socialistas en la mayor central de trabajadores del periodo, la FOCh a finales de $1919^{79}$.

No cabe aquí hacer un recorrido histórico de la $\mathrm{FOCh}^{80}$, pero si es preciso señalar que, entre 1909 y hasta 1919, fue una organización de marcado carácter conciliatorio y mutualista. Es en esta última fecha cuando los socialistas que militaban en la FOCh tomaron el control de esta, imprimiéndole una línea mucho más contestataria, integrándola al poco tiempo, a la Internacional Sindical Roja, ${ }^{81}$ gracias al giro que tuvo Luis Emilio Recabarren junto a otros socialistas, entre ellos Ramón Sepúlveda Leal. Este último, en su

\footnotetext{
75 Para indagar más en el tema, ver http://www.pacarinadelsur.com/home/oleajes/164-arde-la-patria-lostrabajadores-la-guerra-de-don-ladislao-y-la-construccion-forzosa-de-la-nacion-chile-1918-1922. Visto el 05/02/2017.

${ }^{76}$ La Comuna, Viña del Mar, 4 de septiembre de 1920, p.1.

77 La Comuna, Viña del Mar, 4 de junio de 1921, p.3; La Federación Obrera, Santiago de Chile, 11 de septiembre de 1921.

${ }^{78}$ DeShazo, op. cit., p. 238.

${ }^{79}$ Desde ahora, FOCh. Grez (b), op. cit., p. 86.

80 Para un análisis más detallado, ver Vicente Mellado, Del Consejo Federal al Sindicato Legal: La Federación Obrera de Chile (FOCh) y el inicio de la transición a un sistema moderno de relaciones laborales (1919-1927), Informe de Seminario de Grado, Movimientos sociales populares y representaciones políticas en Chile republicano, Universidad de Chile, Santiago de Chile, 2013,; Mario Garcés, Pedros Milos, FOCH, CTCH, CUT. Las Centrales Unitarias en la historia del sindicalismo chileno, ECO, Santiago de Chile, 1988.

${ }^{81}$ Grez (b), op.cit., p.169.
} 
estadía en Concepción, se percató del potencial de la Federación, toda vez que en el Consejo Federal de dicha ciudad participaban los "trabajadores más conscientes, lo más independiente y sólido del elemento obrero". ${ }^{82}$

Estas palabras no quedaron solo en el papel, y el grupo viñamarino, encabezado por Carlos Flores, conformó el 7 de julio de 1918, el Consejo Federal nº 1 de Operarios Fabriles y Oficios Varios, en donde se integraron los obreros pertenecientes a la Refinería de Azúcar, de Seda, de Tejidos Gratry, Fábrica de Lana y Tejidos Caupolicán, teniendo una composición similar a la que tuvo la Unión y Defensa del Trabajo ${ }^{83}$.

La necesidad de organización de los trabajadores viñamarinos dio origen a nuevos Consejos Federales, como el $\mathrm{n}^{\circ} 2$, que integraba a los carpinteros y era dirigido por el socialista Luis A. Salazar ${ }^{84}$; por su parte, el Consejo Federal $n^{\mathbf{0}} 3$ integró a los pintores, mientras que el $\mathrm{n}^{\circ} 4$ a los Empleados y Maestros de Cocina de Ambos Sexos ${ }^{85}$. Finalmente, a fines del periodo estudiado, los socialistas lograron organizar en la ciudad a uno de los gremios más esquivos para ellos, como fueron los metalúrgicos, quienes conformaron el Consejo Federal $n^{0} 5^{86}$. Fue a través de estos consejos que los socialistas pudieron insertarse de una forma más permanente y fuerte en la base del movimiento obrero. Eran los consejos los que convocaban a huelga y solidarizaban con los gremios asociados en los otros consejos, generando así una red de apoyo. Su funcionamiento era a través de un directorio y de delegados, siendo estos últimos los representantes del Consejo en la fábrica o taller, por lo que debían tener ciertas condiciones idóneas para cumplir tal misión ${ }^{87}$.

En las siguientes líneas analizaremos el actuar de los socialistas en el Consejo $\mathrm{n}^{\mathbf{0}} 1$, el cual como ya señalamos anteriormente, era integrado por los trabajadores fabriles de la ciudad como es el caso de las fábricas textiles y de los refineros de la CRAV, siendo dos de los rubros más relevante en la ciudad.

A través de las huelgas en la CRAV se puede rastrear el rol de los socialistas, siendo una de las primeras, la desarrollada en septiembre de 1919. El día cuatro, los obreros de la Refinería de Azúcar se declararon en huelga ante las reiteradas negativas del gerente para responder satisfactoriamente a sus demandas, entre la que se encontraba un aumento en los salarios. Los trabajadores decidieron paralizar las faenas a las doce del día para luego marchar hasta la estación ferroviaria de la ciudad, donde abordaron el tren trasladándose hasta Valparaíso. Una vez en el puerto, se dirigieron a las dependencias de la gerencia de la Compañía. Junto al presidente del Consejo Federal nº 1 de la FOCh viñamarina, así como de

\footnotetext{
${ }^{82}$ El Socialista, Valparaíso 1 de septiembre de 1917.

${ }^{83}$ La Comuna, Viña del Mar, 7 de julio de 1920, p.1. Vicente Mellado señala en su tesis, que los trabajadores de la CRAV "Habían constituido el Consejo Federal de Alimentación de Viña del Mar a mediados de 1919", sin embargo, hemos rastrado que fue el Consejo $\mathrm{n}^{\circ} 1$ de Oficios Varios el que integraron los refineros. Vicente Mellado, "Del Consejo Federal al Sindicato Legal: La Federación Obrera de Chile (FOCh) y el inicio de la transición a un sistema moderno de relaciones laborales (1919-1927). Informe de Seminario de Grado "Movimientos sociales populares y representaciones políticas en el Chile republicano", Universidad de Chile, Santiago, 2013.

${ }^{84}$ La Vanguardia, Valparaíso, 9 de octubre de 1919.

${ }^{85}$ La Comuna, Viña del Mar, 14 de mayo de 1921, p.4.

${ }^{86}$ La Comuna, Viña del Mar, 28 de mayo de 1921, p.4

${ }^{87}$ La Comuna, Viña del Mar, 24 de diciembre de 1919, p.3
} 
otros dirigentes socialistas, tales como Manuel Leiva y Ramón Sepúlveda Leal ${ }^{88}$, además de cuatro delegados de los trabajadores, lograron lo que durante quince días de movilizaciones no habían podido: "el Gerente recibió el pliego y prometió que el Viernes a las 2 P.M, El Director recibiría a la Comisión." ${ }^{89} \mathrm{El}$ aumento de sus jornales que resultó de esta manifestación no fue menor ya que para los hombres que ganaban sueldos inferiores a los $\$ 3,70$ y $\$ 3,75$ diarios se elevaron a $\$ 4,00$; para los que ganaban sobre $\$ 3.75$ se elevó a los $\$ 5,00$. Las obreras también vieron aumentado su jornal: "de $\$ 2,50$ y $\$ 2,75$ que ganaban antes, se elevaron a $\$ 3,00$ y sobre esta suma un aumento de 25 por ciento, o sea un aumento máximo diario de $\$ 1,00$ por día" 90 . Por su parte "Los fogoneros que trabajan la misma guardia a las 24 horas se les abonaba tres días, hoy se le pagará con un aumento de un 25 por ciento, o sea tres cuartos de día más de salario."91 Sorprende ver el grado de deshumanización que alcanzó el sistema capitalista durante este período, permitiendo la existencia de jornadas laborales de veinticuatro horas, acarreando una serie de problemas de salud para quienes realizaban estos turnos. Además, la gerencia reconoció el derecho a la asociación y que cada sección de la fábrica tuviese un delegado del Consejo Federal $\mathrm{n}^{\circ} 1$. En este marco, el balance para La Comuna la movilización podía resumirse "en una palabra, éxito completo" $" 92$. De esta, el triunfo no solo era para los obreros de la Refinería, sino que también para los socialistas, ya que les permitió legitimarse al interior de una de las empresas más grandes de Viña del Mar.

El éxito de la huelga no solo fue atribuido a las capacidades de los dirigentes socialistas y a los obreros paralizados; La Comuna elogió la manera en que el gerente de la empresa había actuado frente a la comisión de trabajadores de la Refinería de Azúcar. El periódico afirmaba que "el Gerente no resultó tan inflexible, a la justicia, a la unión de los obreros y a la disciplina de que dieron prueba; se unió el buen ánimo del Directorio de la Refinería de Azúcar que con el señor Morel al frente estuvo ecuánime y aceptó gran parte de lo que los obreros pedían y exigían"93. La lectura a estas palabras podría indicar que el POS no se encontraba tan alejado de las posturas conciliatorias del PD. Sin embargo, si analizamos la delicada situación en que se encontraban socialistas ante la opinión pública ${ }^{94}$, veremos que los elogios emitidos buscaban apaciguar los temores de la oligarquía viñamarina, demostrando que el POS era un partido que se regía por la institucionalidad política, buscando agotar todos los caminos antes de tomar una medida como la huelga. Esto no era de extrañar a nivel nacional, pues también era la estrategia que asumió principalmente la FOCh, como ha demostrado Peter DeShazo ${ }^{95}$, diferenciándose de la estrategia anarcosindicalista. También podemos señalar que, al reconocer la buena disposición de parte del gerente a aceptar las demandas obreras, los socialistas se

\footnotetext{
${ }^{88}$ La Comuna, Viña del Mar, 13 de septiembre de 1919, p.1.

${ }^{89}$ La Comuna, Viña del Mar, 6 de septiembre de 1919, p.1.

${ }^{90}$ Idem.

91 Idem.

92 Idem.

${ }^{93}$ Idem.

${ }^{94}$ Los ataques eran reiterados de parte del diario La Unión de Valparaíso e iban dirigidos hacia los militantes más reconocidos de Viña del Mar, como Carlos Flores. Para una muestra, ver La Unión, Valparaíso, 16 de enero de 1920.

${ }^{95}$ DeShazo, op. cit., p. 228.
} 
aseguraban poder culpar a la gerencia en una posible escalada del movimiento, como efectivamente sucedió. Esto evidenciaba que el POS por entonces no era un partido eminentemente rupturista con el orden institucional, sino que utilizaba a conveniencia algunos de sus espacios para la acción política y sindical de los trabajadores.

En el mes de febrero de 1920, la Refinería realizó un lock out, paralizando las faenas debido al exceso de producción. Los trabajadores respondieron entregando un nuevo pliego de peticiones, el cual buscaba amortiguar los efectos de la decisión de la empresa, que, de aplicarse, dejaría a cientos de trabajares y trabajadoras cesantes ${ }^{96}$. Por ello, en esta ocasión las palabras de La Comuna hacia Morel, el mismo gerente alabado en septiembre del año anterior, no fueron tan amables. Refiriéndose a él, el periódico señalaba que "se destaca por su despotismo, debe conocerse y gravarse en la mente de cada paria"97. Sin embargo, la idea de poder llegar a un acuerdo con la gerencia de la Refinería llevó a los redactores del periódico a escribir en el número siguiente un artículo en donde señalaron una serie de malentendidos antes de la publicación de su artículo anterior: en primer lugar, aclaraban Morel no habría recibido el petitorio inicial debido a que se encontraba enfermo de gravedad, lo que le impedía recibir cualquier tipo de correspondencia. En segundo lugar, en la comisión elegida para ir a entregar personalmente el pliego de demandas, uno de los miembros se encontraba borracho, mientras que otro de los delegados no supo explicar bien el cometido de aquella visita, por lo que el gerente, molesto, los echó de su casa, hasta donde había llegado la comisión. Finalmente, el redactor señaló que "tal vez obramos con precipitación al calificar en forma dura al Gerente señor Morel, pero, no fue nuestra la culpa" ". Esta "reformulación" de las palabras de los socialistas se hacían más necesarias en un contexto donde la oligarquía atacaba a los obreros, señalándolos como violentistas y fuera de todo orden institucional, teniendo que mostrar lo contrario y apareciendo cautelosos en su actuar. Los dirigentes socialistas buscaron ser los "más responsables" con los obreros de la Refinería de Azúcar, a los cuales estaban representando, toda vez que se jugaba el hambre de cientos de trabajadores.

En un principio, la táctica dio los resultados esperados, ya que se consiguió el compromiso por parte de la gerencia de indemnizar a los trabajadores desvinculados ${ }^{99}$. Pero el compromiso fue roto y en marzo el periódico socialista señaló que las indemnizaciones de las secciones "fuego y casa de carbón" no respondían al monto acordado, llegando a ser menos de un mes de salario, por lo que los trabajadores se negaron a recibirlas ${ }^{100}$. De allí que la tensión entre la empresa y los obreros fue en aumento, generándose una deliberada política de desmovilización por parte de la Refinería, afectando directamente a los socialistas y fochistas. Los socialistas viñamarinos utilizaron las páginas de La Comuna para denunciar las prácticas de la empresa que afectaron directamente a los trabajadores organizados, como la de "desalojar de las viviendas a los obreros que no le son adeptos a sus bastardas peticiones de desorganizar a los trabajadores de la Federación Obrera de Chile [...] se les arroja sin previa notificación de las viviendas que no se les da, sino que se

${ }^{96}$ La Comuna, Viña del Mar, 11 de marzo de 1920, p.1.

${ }^{97}$ Idem.

${ }^{98}$ La Comuna, Viña del Mar, 13 de marzo de 1920, p.1.

${ }^{99}$ Idem.

${ }^{100}$ La Comuna, Viña del Mar, 23 de marzo de 1920, p.4. 
les arrienda en la Ciudadela"101. La inexistencia de más reclamos en el periódico hace pensar que el compromiso se cumplió temporalmente por parte de la CRAV, pero el conflicto volvería a desatarse en diciembre, tras una nueva paralización por parte de la administración debido a una nueva sobreproducción de la Refinería. Una vez más, las negociaciones con la gerencia resultaron en un compromiso de indemnización que iba entre los \$15 a \$10 para las personas que quedasen cesantes, "hasta que se les vuelva a necesitar" 102 .

Si bien el tire y afloja entre empresarios y trabajadores azucareros era permanente, lo que no permite concluir si la influencia socialista y la acción sindical ayudó a mejorar la situación de los obreros, sí queda claro que el POS jugaba un rol importante en el apoyo y conducción de los trabajadores de una de las principales empresas de la ciudad y del país en estos años, lo que evidenciaba la posición estratégica ocupada por los socialistas en el consejo local de la FOCh y la influencia que esta le permitía para insertarse en espacios importantes del mundo obrero urbano de la zona.

La presencia del POS se hizo sentir también durante en las movilizaciones de las fábricas textiles. Con una situación de precariedad similar a los trabajadores de la Refinería de Azúcar, las y los obreros de la Fábrica de Seda de Viña del Mar también decidieron organizarse, quienes desplegaron la huelga más larga del periodo estudiado. Los socialistas desde sus inicios venían desarrollando una política de organización de las mujeres obreras en torno al Despertar de la Mujer (posteriormente denominado Despertar y Defensa de la Mujer), de allí que no fuera extraño que ellas jugaran también un papel importante en la acción sindical socialista viñamarina.

En diciembre de 1919, un número indeterminado de obreras federadas de la Fábrica de la Seda fueron despedidas ${ }^{103}$. Según los socialistas, "los trabajadores y obreras comprendieron inmediatamente de lo que se trataba y se dieron cuenta que el patrón lo único que perseguía era despedir a todas las obreras que pertenencia a la Federación, sembrando el pánico y disponer a su antojo de su suerte"104. Según el análisis del POS, había una clara "persecución" contra los y las trabajadoras organizadas en la FOCh. Pero más allá de eso, en la práctica, un contingente importante de trabajadores de ambos sexos decidió no ingresar a laborar, iniciándose así la huelga. El petitorio era simple: no ser desvinculadas por el solo hecho de ser miembro de la FOCh; en otras palabras, lo que buscaban era que se respetara el derecho de asociación.

El Consejo Federal $\mathrm{n}^{\circ} 1$, a través periódico La Comuna, realizó un llamado a los trabajadores de Viña del Mar para que apoyasen la movilización de las trabajadoras de la seda. También hizo un llamado a manifestarse en apoyo de las huelguistas, el sábado de esa misma semana. Al día siguiente se realizó una matiné que recaudaría fondos destinados a apoyar monetariamente la huelga, costando la entrada la suma $\$ 1.00$; en el mismo número La Comuna señaló que el primer acto de dicha matiné, sería una conferencia a cargo de

${ }^{101}$ La Comuna, Viña del Mar, 22 de mayo de 1920, p.4.

102 La Comuna, Viña del Mar, 4 de diciembre de 1920, p.4.

${ }^{103}$ Existió una fuerte presencia femenina en la Fábrica de Seda. Ver, Jorge Navarro, El lugar de la mujer en el Partido Obrero Socialista. Chile, 1912-1922, Izquierdas, 28, julio 2016. p. 169.

${ }^{104}$ La Comuna, Viña del Mar, 20 de diciembre de 1919, p.4. 
Luis Emilio Recabarren u otro delegado federado ${ }^{105}$. No deja de ser llamativo como la figura de Recabarren era utilizada como un enganche para atraer audiencia. Finalmente, "Don Reca" no asistió a la velada, siendo el dirigente socialista, Carlos Flores, el encargado de dar la conferencia ${ }^{106}$.

El día 24 de diciembre se llevó a cabo una asamblea del Consejo Federal $\mathrm{n}^{\circ} 1$ donde asistieron cuarenta miembros. En aquella reunión se decidió que todos los hombres federados aportaran semanalmente $\$ 1.00$ mientras que las federadas $\$ 50$ centavos a favor de las obreras en huelga. También se dieron otras muestras de apoyo y solidaridad que iban más allá de lo monetario ${ }^{107}$. Ante este panorama, los socialistas anunciaban que era "bien probable que dado el cariz que está tomando este movimiento, se origine una huelga general, por polaridad, así lo ha acordado la Federación Obrera de Chile en una de sus últimas reuniones" "108. Y así fue, pues la huelga de las y los trabajadores de la Fábrica de Seda se extendió por cuarenta días. La profundización de las diferencias entre los obreros paralizados y la administración de la empresa hacían inviable cualquier solución a corto plazo. Estas discrepancias llevaron a que ocurrieran actos de violencia contra algunas huelguistas, llegando incluso a que se le apuntara con un arma de fuego a uno de los trabajadores por parte de un cajero de la empresa:

en la tarde de anteayer, el cajero de la fábrica, provocó un serio incidente que pudo tener fatales consecuencias a no haber estado la oportuna intervención de la policía. Quiso este desequilibrado individuo infundir el terror entre el personal y para esto apuntó sobre un compañero, pero, en el mismo instante le fue quitado el arma, sino hubiera disparado sobre el compañero y quien sabe qué proporción habría adquirido el conflicto.

El oficial que acudió en ese momento uso de mucha benevolencia para con este individuo. Debía de haberlo hecho reducir a prisión, puesto que los códigos castigan estos intentos de homicidio. $^{109}$

A pesar de este hecho de violencia, la postura de la empresa se mantuvo inflexible. Más aún, el gerente de la Fábrica despidió a más de la mitad de sus trabajadoras, aduciendo la escasez de demanda, a lo que el periódico socialista viñamarino replicaba que se podía dar trabajo a todos y todas, siempre y cuando no superaran los cuatros días laborales ${ }^{110}$. Durante el mes de enero, la gerencia realizó una propuesta en la que se señalaba "el derecho de selección", cuestión que los trabajadores podían entender, pero a cambio de una indemnización $^{111}$. No obstante, la organización y constancia mostrada por las huelguistas y el apoyo brindado por los socialistas, las trabajadoras no tenían la fuerza suficiente como para hacer valer esta demanda, quedando en evidencia con el correr de los días. Llegado a este punto, La Comuna se preguntó "¿Por qué no se soluciona la huelga de la fábrica de la seda?" La respuesta venía de su matriz socialista y evidenciaba un claro posicionamiento

\footnotetext{
105 Idem.

${ }^{106}$ La Comuna, Viña del Mar, 24, de diciembre de 1919, p.1.

${ }^{107}$ La Comuna, Viña del Mar, 27 de diciembre de 1919, p.4.

108 Idem.

${ }^{109}$ La Comuna, Viña del Mar, 31 de diciembre de 1919, p.1.

${ }^{110}$ La Comuna, Viña del Mar, 10 de enero de 1919, p.1.

${ }^{111}$ La Comuna, Viña del Mar, 15 de enero de 1920, p.4.
} 
propagandístico, más que explicativo: "La huelga no se soluciona porque el gerente y el presidente de la sociedad están interesados desde hace tiempo en paralizar el movimiento de la industria." "112 La visión de los socialistas no se encontraba muy alejada de la realidad; para los patrones era una verdadera derrota cualquier concesión que pudiesen entregar después de una huelga, ya que creían que fomentaban así la organización y el desacato de parte de los obreros. Era un "gallito" que estaban dispuesto a llevar hasta el límite. Pero lo que no clarificaba La Comuna es que la fuerza de las y los trabajadores también tenía restricciones, siendo una de estas, el desgaste tras varios días movilización.

Lo anterior quedo en evidencia un día después, cuando la huelga finalizó tras cuarenta jornadas en paralización. A pesar de no lograr lo demandado, La Comuna señaló que "al menos la organización supo imponer -consultando todas las necesidades- una solución justa para ambas partes"113. La gerencia permitió la organización de federados y que se nombrasen delegados en las distintas secciones. Sin embargo, no todas las trabajadoras fueron recontratadas, pero aquellas que fueron despedidas al menos lograron ser indemnizadas. Pero, además, algo que fue resaltado por los socialistas como un logro significativo de la movilización, fue la reducción de la jornada laboral a las nueve horas ${ }^{114}$. La presencia de los socialistas en esta movilización fue clara; la podemos ver en la resolución de este conflicto, donde se encuentran los nombres de Carlos Flores y Manuel Leiva entre los firmantes del acuerdo que daba término a la prolongada paralización de los trabajadores de la seda.

A pesar de no ser un triunfo completo, la venia hacia la organización socialista por parte de la administración de la fábrica dio la posibilidad al POS y la FOCh de movilizar a los trabajadores en futuras luchas para poder conseguir lo demandado.

Precisamente fue lo que ocurrió varios meses después de finalizada la huelga, cuando la solución acordada en noviembre se dilató, generando la desconfianza de las trabajadoras de la fábrica, quienes veían cada vez más lejano el cumplimiento del petitorio, sobre todo el punto relacionado con las indemnizaciones. Los socialistas buscaron en el arbitraje una solución favorable, por lo que generaron una comisión arbitral para llevar a buen puerto sus demandas. Por parte de los obreros, el representante fue Ramón Sepúlveda Leal quién logró ponerse de acuerdo con el regidor municipal Carlos Urenda Trigo para elegir un árbitro que acomodara a todas las partes involucradas. Fue así como Antonio Huneeus "distinguido hombre público" "115, como lo denominó el periódico socialista, fue designado para tal tarea.

El conflicto se encendió más, cuando el gerente decidió contratar personal nuevo en vez de llamar a trabajar a quienes habían sido despedidas anteriormente, como era lo acordado. Por esta razón el Consejo $\mathrm{n}^{\circ} 1$ envío un comunicado al subdelegado escrito por Ramón Sepúlveda y Ernesto González a nombre de las trabajadoras de la Fábrica de Seda, señalándole que, como miembro de la comisión arbitral y considerando su cargo, debía tomar carta en el asunto, haciendo cumplir el compromiso ${ }^{116}$. Días después, La Comuna

112 La Comuna, Viña del Mar, 22 de enero de 1920, p.1.

${ }^{113}$ La Comuna, Viña del Mar, 24 de enero de 1920, p.1.

${ }^{114}$ Idem.

${ }^{115}$ La Comuna, Viña del Mar, 28 de febrero de 1920, p.4.

${ }^{116}$ La Comuna, Viña del Mar, 2 de marzo de 1920, p.1 
señaló que se había vuelto a enviar un comunicado al subdelegado, planteándole esta vez que intercediera con el señor Huneeus para realizar nuevas conversaciones entre los representantes de los trabajadores y la empresa, a fin de poder solucionar definitivamente el problema $^{117}$. Con esta presión los trabajadores revirtieron la decisión y la comisión logró que se cumplieran los acuerdos alcanzados anteriormente con la empresa.

Luego de esto, el periódico socialista no informó sobre alguna problemática al interior de la Fábrica hasta diciembre de 1920 cuando, al igual que las otras fábricas del rubro textil, se efectuó un paro forzado desde la empresa, aduciendo la realización de un balance anual. En esta instancia en que La Comuna hizo una fuerte crítica a los y las trabajadoras de las fábricas afectadas, ya que, a juicio de los redactores del periódico, los obreros fueron en parte responsables de lo sucedido, al no estar organizados. En este sentido, probablemente se hayan combinado distintos factores, siendo uno de ellos la coyuntura eleccionaria que se estaba gestando durante esos meses. Efectivamente, los socialistas viñamarinos se abocaron desde el último periodo de 1920 a preparar la candidatura a regidor municipal de Ramón Sepúlveda Leal. El desplazamiento de la centralidad de la lucha sindical se reflejó en que el periódico prácticamente no publicó ninguna noticia sobre la acción laboral de los obreros de Viña del Mar entre marzo y diciembre de 1920. De esta manera queda en evidencia que a pesar del crecimiento que tuvo el POS durante estos años, las fuerzas distaban mucho de ser las necesarias para llevar a cabo en paralelo la lucha sindical y electoral.

Como ya se ha señalado en líneas anteriores, desde sus inicios, los socialistas tuvieron un fuerte interés en las disputas electorales. Si bien el POS era crítico de la "institucionalidad burguesa", buscaron utilizarla con el fin de dar a conocer su crítica a la oligarquía y sus propuestas de una nueva sociedad socialista. De la experiencia electoral en 1918, la sección viñamarina concluiría que era más probable obtener un sillón en el municipio que un cupo en el parlamento, por lo que las elecciones de 1921 significaron una concentración de las fuerzas en la elección municipal, siendo Ramón Sepúlveda Leal elegido como candidato. Así lo indicaba La Comuna el día 4 de febrero de 1920, cuando señaló que:

El Partido Obrero Socialista, en Viña del Mar, no lleva en esta ocasión candidato a diputado ni a senador. Al obrar así, lo hemos hecho por que queremos guardar todas nuestras energías para la elección de municipales, en la que dedicaremos todos nuestros esfuerzos a objeto de que sea una realidad el triunfo de nuestro camarada Ramón Sepúlveda $\mathrm{L}^{118}$.

El trabajo realizado por Sepúlveda en Viña del Mar desde su llegada en 1910, y aún más una vez ingresado al POS, le significó un reconocimiento a tanto a nivel local como nacional, que avalaba su candidatura.

Para los socialistas, la Municipalidad era la institución en donde daban soluciones a los temas como la limpieza y cuidado de la ciudad, la higiene de los alimentos que se vendían y la mantención de hospitales entre otros. Es por esto que La Comuna señalaba que

${ }^{117}$ La Comuna, Viña del Mar, 13 de marzo de 1920, p.1

${ }^{118}$ La Comuna, Viña del Mar, 4 de marzo de 19210, p.1. 
la "clase obrera organizada que lucha y trabaja por mejorar las condiciones de vida, no puede desentenderse, ni negarse a comprender que la municipalidad dirigida por obreros realizaría espléndidamente todo ese magnífico programa social que dejamos trazado"119.

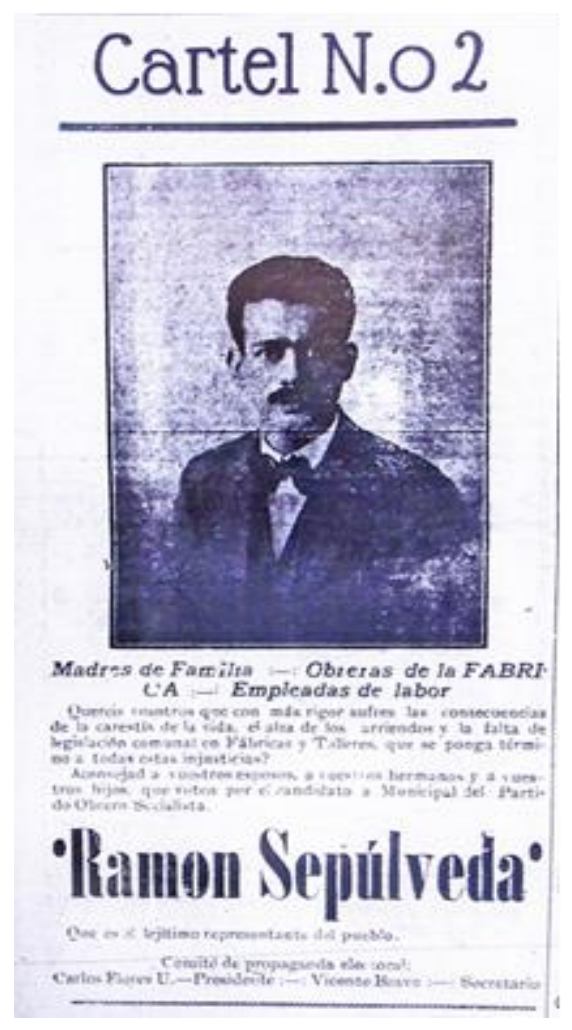

Las irregularidades propias del sistema político chileno se reflejaron en una serie de problemáticas al interior del municipio, lo que hizo complejo el escenario para la elección de $1921^{120}$. Semanas antes de que Sepúlveda fuese proclamado como candidato, $L a$ Comuna publicó una nota donde señalaba que antes de cualquier elección, el Club de Viña del Mar, institución donde se reunía la aristocracia viñamarina, recolectaba entre sus socios dinero suficiente para comprar el voto de quinientos hombres, lo que no era una cifra descabellada, teniendo en cuenta, lo extendido, a nivel nacional, de la práctica del cohecho. En el mismo reportaje, se señaló que, en el Partido Radical, cualquiera que juntara ocho o siete mil pesos, era un posible candidato. También señalaba que "nacionales" e independientes eran más conservadores que los mismos militantes del Partido Conservador. Eran estos, a juicio de La Comuna, los partidos que cada tres años se repartían los sillones municipales ${ }^{121}$.

La Comuna, 4 de diciembre, 1920

El día 19 de octubre de 1920, el POS celebró una reunión donde se concretó que "la necesidad de definir actitud y personas en lo que se refiere a política local, por considerar de útil conveniencia para el éxito de las futuras luchas del partido, se acordó hacer la elección de candidato a municipal"122. El candidato proclamado fue Ramón Sepúlveda Leal, conformándose de inmediato una comisión integrada por los militantes socialistas Flores, Vial, Aliaga y Bravo, la cual estuvo a cargo de los trabajos electorales ${ }^{123}$.

${ }^{119}$ La Comuna, Viña del Mar, 15 de noviembre de 1919, p.2.

120 A modo de ejemplo, ver La Comuna, 20 de septiembre de 1919, p.4; La Comuna, 22 de noviembre de 1919, p.1.

${ }^{121}$ La Comuna, Viña del Mar, 16 de octubre de 1920, p.1.

${ }^{122}$ La Comuna, Viña del Mar, 6 de noviembre de 1920, p.4.

${ }^{123}$ Idem. 
Al igual que en las elecciones pasadas, los socialistas utilizaron imágenes como herramienta para llegar a los trabajadores. Es así como el día 11 de diciembre, La Comuna publicó el primero de los "Carteles Políticos" en donde mostraban una fotografía de Sepúlveda junto a una breve semblanza y a un llamado a obreros, empleados y a "los comerciantes honrados" de Viña del Mar a votar por él. ${ }^{124}$ En los siguientes seis números de La Comuna, el "Cartel Político" realizó llamados a distintos actores a votar por Sepúlveda. Interesante es ver que, en el segundo de estos carteles, el periódico apuntó a las madres de familias, obreras de fábricas y empeladas, puesto que a pesar de que las mujeres estaban imposibilitadas de participar, el llamado fue a "Aconsejad a vuestros esposos, a vuestros hermanos y a vuestros hijos que voten por el candidato Municipal del Partido Obrero Socialista"125. Esto ratificaba la permanente interpelación política que hacían los socialistas de Viña del Mar al mundo femenino. A lo anterior, se sumó la creación de un Comité Central de Propaganda encargado de nombrar subcomités barriales, de la circulación de una boleta para reunir firmas en apoyo a la candidatura de Sepúlveda Leal, preparar una "Liga contra el cohecho y de la logística para veladas y mítines públicos con el fin de dar a conocer el programa del candidato socialista"126. El 5 de enero y ante 65 asambleístas, se decidió dividir la propaganda en interna y general. En esta última categoría, jugaron un rol importante, los cinco subcomités de propaganda que se formaron en la misma reunión (barrio Población Vergara, barrio Bolívar Cancha-Álvarez, Población Forestal, calle Limache y Refinería, Centro, Chorrillo y 16 norte y finalmente Caleta Abarca), cuyo objetivo inmediato fue informar sobre el programa y el candidato del POS de una manera más directa con el mundo popular de la ciudad, principalmente los trabajadores. La primera tarea de estos subcomités fue la elaboración y posterior repartición de boletas de adhesión a favor del candidato del POS. ${ }^{127}$ La Comuna informó el 22 de enero que "Los Sub-Comités de barrios están empeñados en una ardua labor, se han efectuado conferencias callejeras que han sido acogidas con entusiasmo por los vecinos"128. La administración de La Comuna también fue un actor relevante de la campaña, comprando "un lote de papel averiado, que le permitirá a Manuel Leiva dar material para tirar en el curso del presente mes unos 50.000 CARTELES DE PROPAGANDA"129.

La cercanía de Sepúlveda con Recabarren posibilitó que este último apoyara públicamente la candidatura del candidato socialista en una concentración llevada a cabo el 19 de diciembre en el Centro Obrero perteneciente al $\operatorname{POS}^{130}$. A esto se sumó la realización de una velada a beneficio de la candidatura, la cual buscó recaudar fondos para la propaganda del candidato socialista. Como era costumbre en estas actividades, la velada no solo contó con discursos políticos, sino que también culturales. Es así como la obertura de la noche estuvo a cargo de una tal señora Guzmán, la cual tocó algunos temas en piano. Fue

\footnotetext{
${ }^{124}$ La Comuna, Viña del Mar, 27 de noviembre de 1920, p.2.

${ }^{125}$ La Comuna, Viña del Mar, 4 de diciembre de 1920, p.4.

${ }^{126}$ La Comuna, Viña del Mar, 1 de enero de 1921, p.4.

${ }^{127}$ La Comuna, Viña del Mar, 8 de enero de 1921, p.4.

${ }^{128}$ La Comuna, Viña del Mar, 22 de enero de 1921, p.4.

${ }^{129}$ La Comuna, Viña del Mar, 4 de marzo de 1921, p.1. Las mayúsculas son del original.

${ }^{130}$ La Comuna, Viña del Mar, 25 de diciembre de 1920, p.3.
} 
seguida por el coro del Cuadro Dramático Carlos Marx finalizando la jornada con un baile ${ }^{131}$.

El 26 de marzo se proclamó oficialmente a Sepúlveda, en un acto realizado en la Plaza Vergara. La Comuna cifró la asistencia en cerca de 2.000 obreros, entre hombres y mujeres. Sin embargo, creemos difícil que se haya alcanzado esta cifra, sobre todo por la escasa información que entrega el periódico en torno a tal evento, ${ }^{132}$ lo que no significa que haya sido poco numerosa la columna de trabajadores que demostró su apoyo al candidato socialista.

Finalmente, el 10 de abril se llevaron a cabo las elecciones. Por un margen muy estrecho, a pesar de los pronósticos del POS, de la presencia de la "Guardia Roja", un grupo de mujeres socialistas ${ }^{133}$ que estuvo a cargo de evitar el cohecho, las cuales incluso fueron amenazadas con el revolver de uno de los "ganchos" que andaba reclutando personas para que votaran por el candidato Santos Ruiz ${ }^{134}$ y los llamados realizado por el candidato socialistas ese mismo día a boca de urna, no se logró el triunfo.

Los socialistas responsabilizaron de la derrota a una serie de irregularidades acaecidas durante el conteo de los votos. En un primer computo se dio por ganadores la lista de los cuatros radicales, un liberal independiente y al mismísimo Sepúlveda. Esto era una sorpresa para todos y según los datos que entrega La Comuna, el mismo día el derrotado Santos Ruiz echó a correr el rumor de que Sepúlveda había falsificados votos, con el objetivo de desconocer su triunfo. La acusación de los socialistas podría ser plausible, sobre todo si se considera que Santos llevaba 27 años consecutivos en cargos municipales ${ }^{135}$, por lo que la derrota a manos de un socialista como Sepúlveda debe haber sido un duro golpe, urdiendo una serie de intrigas para no perder su puesto. El reclamo forjado por los miembros del Partido Nacional del cual fue candidato Santos fue aceptado por el Colegio Electoral, quitándole el triunfo en los días siguientes a Ramón Sepúlveda Leal. Ante esta situación, los socialistas ocuparon el derecho a reclamación "pidiendo la revisión de los votos que fueron al Senado para que ante testimonio notarial se nos escruten los nuevos votos correspondientes a la cedula que no se nos quiso escrutar en la mesa 5.a" $" 136$.

El Tribunal de Honor que debía definir el futuro de Sepúlveda Leal en el municipio estuvo compuesto principalmente por los aliancistas, ya que estos tuvieron mayoría en el nuevo municipio. El día fijado para la entrega del resultado fue el $1^{\circ}$ de mayo. Las manifestaciones, aseguraba La Comuna, se harían sentir en las calles de Viña del Mar hasta esa fecha. En ocasión del número especial publicado el 30 de abril, el periódico hizo un llamado para que los trabajadores fueran a demostrar al día siguiente el apoyo Sepúlveda

\footnotetext{
${ }^{131}$ La Comuna, Viña del Mar, 15 de enero de 1921, p.4.

${ }^{132}$ La Comuna, Viña del Mar, 2 de abril de 1921, p.4.

${ }^{133}$ De este núcleo de mujeres, posteriormente se formaría el Centro Femenino "Rosa Luxemburgo". La Comuna, Viña del Mar, 28 de mayo de 1921, p.1.

${ }^{134}$ La Comuna, Viña del Mar, 16 de abril de 1921, p.1.

135 Esta información es corroborada al analizar la lista de regidores desde 1891 hasta 1921, en donde Ruiz Santos ocupó este cargo durante este periodo, a excepción de los años 1894 a 1897 https://sites.google.com/site/archivohistoricopatrimonial/alcaldes-regidores-y-concejales

${ }^{136}$ La Comuna, Viña del Mar, 16 de abril de 1921, p.1.
} 
Leal, llamando a la prudencia ante el resultado, que se previa desfavorable ${ }^{137}$. Sin embargo, el Tribunal de Honor dio finalmente el triunfo definitivo a Ramón Sepúlveda Leal, excluyéndose al candidato "nacional" Santos de la Municipalidad, por lo que los nuevos miembros municipales fueron don Carlos Jara Torre como Primer Alcalde, Segundo alcalde, Guillermo Mayne Silva, Tercer Alcalde Carlos Comelli y los regidores Julio Gómez Videla, Díaz Anabalón y Sepúlveda Leal ${ }^{138}$. Así, tras casi una década de desarrollo en la zona, los socialistas pasaban formar parte del municipio de Viña del Mar.

Una vez asumido como regidor municipal, Sepúlveda tuvo enfrentarse a una serie de problemas que entorpecieron su desarrollo en el cargo. Conformado el gobierno municipal definitivo, La Comuna señaló que la Municipalidad "no ha celebrado sesión ordinaria ni extraordinaria, tanto por la enfermedad del regidor Mayne como por la inasistencia de algún otro regidor de la mayoría"139, lo que hizo imposible que el ahora regidor socialista llevase a cabo sus políticas sociales. La sesión inicial se realizó recién el 28 de mayo, en donde Sepúlveda pasó a conformar la comisión de "Policía de aseo, higiene y salubridad". Asimismo, hizo una serie de acusaciones en contra de la administración anterior por haber dejado indefensos a los pobladores de Forestal ante los terratenientes que vendieron terrenos indiscriminadamente en la plaza de esta población, sin hacer los arreglos sanitarios necesarios, lo que les permitió a estos enriquecerse. También acusó a las tabernas clandestinas existentes en la ciudad, exigiendo medidas para combatirlas, acusaciones que recibieron el apoyo del segundo alcalde Mayne. Finalmente, denunció la existencia de una Escuela Federal que era financiada por la municipalidad pero que no existía en la práctica, solicitándole al primer alcalde que hiciese todas las averiguaciones necesarias para su cierre $^{140}$.

Buscando diferenciarse de los políticos tradicionales, Sepúlveda convocó a través de La Comuna, a una asamblea el martes 28 de junio, para dar cuentas públicas a sus electores de lo realizado en el municipio hasta ese momento, así como pedir "instrucciones al obrerismo viñamarino para su conducta a seguir como representante del pueblo"141.

Hacia julio de 1921, la municipalidad nuevamente dejo de sesionar, viéndose paralizando el proyecto presentado por Sepúlveda para conseguir un anticipo de 300 mil pesos que se necesitaban para financiar las arcas municipales que se encontraban vacías debido a la mala gestión anterior ${ }^{142}$. El 25 del mismo mes, el regidor socialista dio por segunda vez una cuenta pública, esta vez en sesión del POS, donde asistieron 32 asambleístas. En esta ocasión, Sepúlveda expuso las problemáticas de las poblaciones obreras y la solicitud enviada por parte de la municipalidad en reiteradas ocasiones a la Empresa de Tranvías para que mejorara sus servicios. Señaló también que logró que el Primer Alcalde tomara fuertes medidas para castigar los prostíbulos y tabernas clandestinas. Sepúlveda recibió, a su vez, indicaciones de los asambleístas sobre los pasos a seguir al

${ }^{137}$ La Comuna, Viña del Mar, 30 de abril de 1921, p.5.

${ }^{138}$ La Comuna, Viña del Mar, 7 de mayo de 1921, p.1.

${ }^{139}$ La Comuna, Viña del Mar, 21 de mayo de 1921, p.4.

${ }^{140}$ La Comuna, Viña del Mar, 4 de junio de 1921, p.4.

${ }^{141}$ La Comuna, Viña del Mar, 25 de junio de 1921, p.4.

${ }^{142}$ La Comuna, Viña del Mar, 9 de julio de 1921, p.1. 
interior del municipio ${ }^{143}$. En noviembre de ese mismo año, Sepúlveda expuso su postura en la sesión ordinaria ante la posibilidad de que se construyeran líneas de tranvías en la ciudad, especialmente en las zonas populares. Ante la negativa del consejo de aceptar las condiciones de la Empresa Ferroviaria de Valparaíso, Sepúlveda señaló que "deben agotarse todos los medios posibles para tartar de obtener que se instalen líneas de tranvías en los barrios obreros" $" 144$.

En la primera sesión de 1922, Sepúlveda realizó una indicación con el objetivo de aumentar el dinero del presupuesto de subvenciones a los establecimientos de instrucción pública, el cual no fue aceptado, pero tampoco rechazado, siendo derivado a la comisión de Hacienda del Municipio ${ }^{145}$, demostrando así la preocupación del regidor socialista por la educación de la localidad. Será la sesión del 15 de marzo de 1922 en la que se plasme de mejor manera las preocupaciones del regidor socialista y su actuar dentro del municipio. Junto con el regidor Díaz, propusieron tratar el tema de la inexistencia de desagües en el sector de Vista al Mar, quedando como resolución, la conformación de una Comisión que pudiese presionar a la Compañía de Desagües para instalarlos. Asimismo,

El regidor señor Sepúlveda manifiesta que hace tiempo se presenta una solicitud de los vecinos de Chorrillos, pidiendo la apertura de una calle que sin derecho mantiene cerrada el señor Eliseo Gutiérrez, petición que fue desatendida. Solicita que se reconsidere ese acuerdo en vista de los nuevos antecedentes que obran en la Alcaldía en los que se establece que dichos terrenos forman parte de la calle cuya apertura se pide. Después de un corto debate la sala acuerda proceder a efectuar la apertura de la calle Valdés Vergara de Chorrillos que indebidamente mantiene cerrada don Eliseo Gutiérrez. ${ }^{146}$

Consideramos que estas dos propuestas de Sepúlveda demuestran su clara preocupación localista, aprovechando la municipalidad para dar soluciones a problemáticas concretas sufrida por los vecinos de la ciudad, pero especialmente por los y las trabajadoras, las cuales eran ignorados constantemente por las autoridades. Vemos también un claro respeto por la institucionalidad, ya que, en la revisión de las actas, se puede observar la utilización de un lenguaje cortes y conciliador por parte de Sepúlveda, muy distinto al utilizado en sus escritos o en sus discursos.

Luego de una pausa de seis meses en las sesiones municipales, Sepúlveda es expulsado del cargo, tras la sentencia del Primer Juzgado Civil dándole el favor al ex candidato Santos, quien había denunciado irregularidades en la elección de 1921, siendo este último reintegrado definitivamente a la municipalidad en desmedro de Sepúlveda ${ }^{147}$.

\footnotetext{
${ }^{143}$ La Comuna, Viña del Mar, 30 de julio de 1921, p.1.

144 Sesión Ordinaria celebrada el 9 de noviembre de 1921, Actas de la Municipalidad de Viña del Mar, 19211923

145 Sesión Ordinaria celebrada el 4 de enero de 1922, Actas de la Municipalidad de Viña del Mar, 1921-1923

146 Sesión Ordinaria celebrada el 15 de marzo de 1922, Actas de la Municipalidad de Viña del Mar, 19211923.

147 Sesión Ordinaria celebrara el 16 de agosto de 1922, Actas de la Municipalidad de Viña del Mar, 19211923.
} 
Sin embargo, la tarea del máximo dirigente del socialismo y comunismo en la ciudad continuaría, pero desde otro lugar. En enero de 1922, en el Congreso de Rancagua, el POS resolvió cambiar su nombre por el de PCCh, siendo elegido un nuevo Comité Ejecutivo Nacional. El cargo de Secretario General recayó en Sepúlveda, mostrando no solo un reconocimiento a sus capacidades y liderazgo dentro del partido, sino que también fue un reconocimiento a la labor realizada por los socialistas durante todo este periodo en Viña del Mar.

\section{Conclusiones}

El POS viñamarino fue un actor relevante en el movimiento obrero viñamarino durante gran parte de la década de 1910 y principio de la siguiente. A través de una política sindical, creando organizaciones como la Sociedad de Resistencia Oficios Varios, Unión y Defensa del Trabajo y posteriormente por medio de los Consejos Federales pertenecientes a la FOCh, los militantes socialistas lograron algunos triunfos para los y las trabajadoras industriales de la ciudad, beneficios que se tradujeron en aumento de salarios, reducción de la jornada laboral, respeto al derecho de asociación, etc. En el periodo de consolidación del partido en la ciudad, entre 1919 a 1922, el POS tuvo una fuerte presencia al interior de las grandes industrias de la ciudad, como lo fueron la Fábrica de la Seda y la Refinería de Azúcar. Asimismo, militantes socialistas fueron el nexo entre los trabajadores con las autoridades y el gobierno en distintas ocasiones, lo que demuestra un reconocimiento no solo de parte de los obreros, sino que también de la institucionalidad. El interés de los socialistas en el mundo del trabajo permitió que los trabajadores se organizaran bajo el alero de los postulados del POS, generando una cultura sindical en una ciudad con un amplio número de obreros y obreras, que se movilizaron en busca de mejoras laborales y de vida.

En el ámbito electoral, es posible afirmar que, a pesar de los negativos resultados de las elecciones de 1915 y 1918, el POS logró evaluar la naciente fuerza del partido y aprender de los errores, permitiendo así que, en un lustro, conseguir los primeros parlamentarios a nivel nacional y en una década, un diputado por la zona ${ }^{148}$. En relación con lo anterior es que el POS viñamarino optó, siguiendo una línea política similar a la adoptada a nivel nacional, por participar en la elección municipal de 1921. Esto, más el cambio en la correlación de fuerza en la política nacional que generó el triunfo presidencial de Arturo Alessandri Palma en 1920, permitieron que, por primera vez, un socialista llegara al municipio viñamarino, demostrando así un apoyo electoral que, a pesar de haber sido escaso numéricamente, no deja de ser relevante, toda vez que los vicios del sistema, como el cohecho, impedían una real participación de las mayorías. A esto hay que sumar que un gran contingente femenino, militante o cercano al POS, le era negado el votar, producto de la prohibición que tenían las mujeres para participar en los procesos eleccionarios. De habérseles permitido, con seguridad el número de votos habría sido mayor, dado que el POS tenía una fuerte llegada en las proletarias de la ciudad. Lo anterior nos permite concluir que el caso de Viña del Mar muestra cómo el POS

${ }^{148}$ Ramón Sepúlveda Leal se convirtió en diputado por Valparaíso en 1925. 
utilizando una estrategia amplia, consolidado su trabajo político y sindical en la ciudad, lo que nos permite matizar la perspectiva del historiador Peter DeShazo en cuanto a la hegemonía ácrata en las zonas urbanas del centro del país. Más parece ser que la historia de los partidos subalternos nos muestra que, los gobiernos locales han sido incorporados como un primer peldaño, ya sea para satisfacer demandas de la población, así como también pensar en un proceso futuro de transformación revolucionaria de la sociedad, lo cual puede ser una explicación del camino institucional tomado tanto por los comunistas como por los socialistas durante gran parte del siglo XX en Chile. Asimismo, el que no se haya podido identificar durante la revisión del fondo municipal alguna información sobre huelgas, especialmente en el periodo en que Sepúlveda tuvo un cargo, nos permite concluir que el municipio era visto, muy acertadamente, como un espacio no apto para solucionar las grandes demandas obreras, pero, como alimentación, vestuario, trabajo, etc., pero si para generar medias paliativas y más inmediatas para estas mismas demandas.

La utilización variada de accionar propagandísticas, como el contacto directo con la población, a través de afiches, pero principalmente de mítines callejeros, pareció ser la táctica preferida por los socialistas viñamarino, llevando el discurso socialista al seno de los barrios obreros y populares de la ciudad. A su vez, la prensa socialista jugó un papel relevante en el periodo estudiado, especialmente La Comuna, no solo informando, haciendo llamados a huelgas y reuniones, sino que generando distintos espacios de sociabilidad entre los obreros de la ciudad. Esperamos así que esta investigación haya aportado elementos relevantes para entender una parte del desarrollo del POS en la ciudad como también haya contribuido aspectos de la historia local de Viña del Mar.

\section{Fuentes y bibliografía}

\section{a. Libros}

- Ansaldi, Waldo, Giordano, Verónica, América Latina la construcción del orden. Tomo I De la Colonia a la dominación oligárquica, Ariel, Buenos Aires, Argentina, 2012.

- Arias, Osvaldo, La Prensa Obrera en Chile, Servicio Central de Extensión y Acción Social Oficina de Difusión y Publicaciones, Universidad de Chile-Chillán, Chillán, 1970.

Ramón Sepúlveda Leal, Centro de Estudios del movimiento obrero Salvador Allende, México D.F, México, 1983.

- Barría, Jorge, El Movimiento obrero en Chile. Síntesis histórico-social, Editorial Trigomo, Santiago de Chile, 1971.

- Del Pozo, José, Historia de América Latina y el Caribe, 1825-2001. LOM Ediciones, 2002, Santiago de Chile.

- DeShazo, Peter, Trabajadores urbanos y sindicatos en Chile: 1902-1927, Centro de Investigación Diego Barros Arana, Santiago de Chile, 2007.

- Garcés, Mario, Crisis Social y Motines Populares en el 1900, LOM Ediciones, Santiago de Chile, 2003.

- Garcés, Mario, Milos, Pedro, FOCH, CTCH, CUT. Las Centrales Unitarias en la historia del sindicalismo chileno, Educación y Comunicación LTDA, Santiago de Chile, 1988.

- Grez, Sergio, De la "Regeneración del Pueblo" a la Huelga General. Génesis y evolución histórica del movimiento popular en Chile (1810-1890), RIL Editores, Santiago de Chile, 2007. 
$-$ Ediciones, Santiago de Chile, 2011.

- Los anarquistas y el movimiento obrero. La alborada de "la Idea" en Chile, 1893 1915, LOM Ediciones, Santiago de Chile, 2007.

- $\quad$ El Partido Democrático de Chile. Auge y ocaso de una organización política popular (1887-1927), LOM Ediciones, Santiago de Chile, 2016.

- Hobsbawm, Eric, Historia del Siglo XX 1914-1991, Critica, Barcelona, 2001.

- Massardo, Jaime, La formación del imaginario político de Luis Emilio Recabarren. Contribución al estudio crítico de la cultura política de las clases subalternas de la sociedad chilena, LOM Ediciones, Santiago de Chile, 2008.

- Núñez, Luz, El obrero ilustrado. Prensa obrera y popular en Colombia.1909-1929, Ediciones UniAndes, Bogotá D.C., Colombia, 2006.

- Ortiz, Fernando, El Movimiento Obrero en Chile (1891-1919), LOM Ediciones, Santiago de Chile, 2005.

- Pinto, Julio, Luis Emilio Recabarren. Una biografía histórica. LOM Ediciones, Santiago de Chile, 2013.

- Pinto, Julio, Valdivia, Verónica, ¿Revolución proletaria o Querida Chusma? Socialismo y Alessandrimo en la pugna por la politización pampina (1911-1932). LOM Ediciones, Santiago de Chile, 2001.

$-$ 1840), LOM Ediciones, Santiago de Chile, 2009.

- Pizarro, Crisóstomo, La Huelga Obrera en Chile, Ediciones Sur, Santiago de Chile, 1986.

- Ramírez, Hernán, Obras Escogidas. Volumen I, Historia del Movimiento Obrera en Chile, LOM Ediciones, Santiago de Chile, 2007.

- _ Obras Escogidas. Volumen II, Origen y formación del Partido Comunista de Chile, LOM Ediciones, Santiago de Chile, 2007.

- Sunkel, Guillermo, Razón y Pasión en la Prensa Popular. Un estudio sobre cultura popular, cultura de masas y cultura política, Publicaciones El Buen Aire S.A., Santiago de Chile, 2016.

- Thompson, Edward, La Formación de la Clase obrera en Inglaterra, Capitán Swing, España, 2012.

- Valenzuela, Humberto, Historia del Movimiento Obrero chileno, Editorial Quimantú, Santiago de Chile, 2008.

- Vítale, Luis, Interpretación Marxista de la Historia de Chile. Volumen III (tomos V y VI), LOM Ediciones, Santiago de Chile, 2011.

- Zaida, Mirta, La Prensa Obrera. Buenos Aires y Montevideo. 1890-1958, Edhasa, Buenos Aires, 2009.

\section{b. Artículos}

- Garrido, Eugenia, Los orígenes de Viña del Mar y su proceso de industrialización, un caso específico: Lever, Murphy y CIA, Revista Archivum, Año V, № 6, Viña del Mar, pp. 74-86

- Montaner, Lorena, Los verdaderos orígenes de Viña del Mar y un símbolo de este proceso: La Refinería de Azúcar de Viña del Mar (CRAV), Revista Archivum, año VII, No 8, Viña del Mar, 2005, pp. 75-85.

- Donoso, Karen, Las mordazas a la prensa obrera. Los mecanismos de la censura política en Chile, 1919-1925, Izquierdas, nº 28, 191-225, julio, 2016.

- Pinto, Julio, El despertar del proletariado: El Partido Obrero Socialista y la construcción de la identidad obrera en Chile", Hispanic American Historical Review, 86:4, 2006, pp. 707-745

- Socialismo y salitre: Recabarren, Tarapacá y la formación del Partido Obrero Socialista, Historia, vol. 32, 1999, pp. 360-362 
- Urbina, María Ximena, Chalets y Chimeneas: los primeros establecimientos industriales viñamarinos, 1870-1920. Revista Archivum, año IV, No 5, Viña del Mar, 2003, pp. 173-196

- Urtubia, Andrés, Viña del Mar en los inicios del siglo XX. Entretenimiento y ocio. Complemente a los baños de mar, Revista Archivum, año VII, No 8, Viña del Mar, 2005, pp. 143-149

- Navarro, Jorge, El lugar de la mujer en el Partido Obrero Socialista. Chile, 1912-1922, Izquierdas, 28: 162-190, julio 2016.

\section{c. Tesis}

- Mella, Vicente, Del Consejo Federal al Sindicato Legal: La Federación Obrera de Chile (FOCh) y el inicio de la transición a un sistema moderno de relaciones laborales (1919-1927), Informe de Seminario de Grado: Movimientos sociales populares y representaciones políticas en Chile republicano, Universidad de Chile, Santiago de Chile, 2013.

- Navarro, Jorge, La construcción de la cultura política del Partido Obrero Socialista. Factores, elementos y particularidades de la acción socialista, 1912-1918, Tesis para optar al grado de Magíster en Historia, mención Historia en América, Universidad de Santiago de Chile, Santiago de Chile, 2015.

- Riquelme, Daniel, Identidad y proyecto político en la construcción del Partido Obrero Socialista. Santiago y Valparaíso, 1912-1916. Informe final para optar al grado de Licenciado en Historia. Seminario de Grado: Movimientos sociales populares y representaciones políticas en Chile republicano, Universidad de Chile, Santiago de Chile, 2013.

- Riffo, Diego, “PPor las Fábricas de Viña del Mar!”: La presencia del Partido Obrero Socialista en Viña del Mar. 1919-1921. Un análisis a través del periódico La Comuna. Tesis para optar a los grados académicos de Licenciado en Historia, Licenciado en Educación y Título Profesional de Profesor de Enseñanza Media en Historia y Ciencias Sociales, Universidad de Valparaíso, Valparaíso, 2016.

- Rodríguez, Ignacio, Protestas y Soberanía Popular: Las Marchas del Hambre en Santiago de Chile 1918-1919, Tesis para optar al grado de Licenciado en Historia, Santiago de Chile, PUCV.

$-$

\section{Fuentes}

- $\quad$ El Socialista, Valparaíso, 1915-1918.

- La Batalla, Santiago, 1913-1916.

- La Comuna, Viña del Mar, 1919-1921.

- La Defensa Obrera, Valparaíso 1913-1915.

- La Federación Obrera, Santiago, 1921-1922.

- La Unión, Valparaíso, 1920-1921.

- La Vanguardia, Valparaíso. 1919-1920. 